\title{
Development of a road transport emission inventory for Greece and the Greater Athens Area: Effects of important parameters
}

\author{
K.M. Fameli ${ }^{\mathrm{a}, \mathrm{b}, *}$, V.D. Assimakopoulos ${ }^{\mathrm{b}}$ \\ a Department of Environmental Physics and Meteorology, Faculty of Physics, University of Athens, Building Physics V, University Campus, Athens 157 84, Greece \\ ${ }^{\mathrm{b}}$ Institute for Environmental Research and Sustainable Development, National Observatory of Athens, Palaia Penteli, 15236 Athens, Greece
}

\section{H I G H L I G H T S}

- A spatially and temporally resolved emission inventory (Greece-Athens)

- Development of temporal coefficients for the disaggregation of road emissions

- Engine technology and fuel consumption determine annual variation of emissions.

- $40 \%$ of national CO, VOC and NMVOC and $30 \%$ of NOx and PM are emitted in Athens.

- $\mathrm{CO}, \mathrm{VOC}$ and NOx are more sensitive to fleet composition and fuel type.

\section{A R T I C L E I N F O}

\section{Article history:}

Received 12 June 2014

Received in revised form 5 August 2014

Accepted 6 October 2014

Available online $\mathrm{xxxx}$

Editor: Pavlos Kassomenos

\section{Keywords:}

Emission inventory

Road transport

Dieselisation

Temporal coefficients

Athens

Greece

\begin{abstract}
A B S T R A C T
Traffic is considered one of the major polluting sectors and as a consequence a significant cause for the measured exceedances of ambient air quality limit values mainly in urban areas. The Greater Athens Area (located in Attica), the most populated area in Greece, faces severe air pollution problems due to the combination of high road traffic emissions, complex topography and local meteorological conditions. Even though several efforts were made to construct traffic emission inventories for Greece and Attica, still there is not a spatially and temporally resolved one, based on data from relevant authorities and organisations. The present work aims to estimate road emissions in Greece and Attica based on the top down approach. The programme COPERT 4 was used to calculate the annual total emissions from the road transport sector for the period 2006-2010 and an emission inventory for Greece and Attica was developed with high spatial ( $6 \times 6 \mathrm{~km}^{2}$ for Greece and $2 \times 2 \mathrm{~km}^{2}$ for Attica) and temporal (1-hour) resolutions. The results revealed that about $40 \%$ of national $\mathrm{CO}_{2}, \mathrm{CO}, \mathrm{VOC}$ and $\mathrm{NMVOC}$ values and $30 \%$ of NOx and particles are emitted in Attica. The fuel consumption and the subsequent reduction of annual mileage driven in combination with the import of new engine anti-pollution technologies affected $\mathrm{CO}_{2}, \mathrm{CO}$, VOC and NMVOC emissions. The major part of $\mathrm{CO}(56.53 \%)$ and $\mathrm{CO}_{2}(66.15 \%)$ emissions was due to passenger cars (2010), while heavy duty vehicles (HDVs) were connected with $\mathrm{NOx}, \mathrm{PM}_{2.5}$ and $\mathrm{PM}_{10}$ emissions with $51.27 \%, 43.97 \%$ and $38.13 \%$ respectively (2010). The fleet composition, the penetration of diesel fuelled cars, the increase of urban average speed and the fleet renewal are among the most effective parameters towards the emission reduction strategies.
\end{abstract}

(c) 2014 Elsevier B.V. All rights reserved.

\section{Introduction}

According to the Air quality in Europe - 2013 report (EEA, 2013a) up to a third of Europeans living in urban areas are exposed to air pollutant levels that exceed the European Union air quality standards thus posing a threat to the urban environment and human health (Hoek et al., 2002). Traffic is considered one of the major polluting sectors and as a

\footnotetext{
* Corresponding author at: Department of Environmental Physics and Meteorology, Faculty of Physics, University of Athens, Building Physics V, University Campus, Athens 157 84, Greece. Tel.: + 302107276914.

E-mail addresses: kmfameli@phys.uoa.gr, kmfameli@noa.gr (K.M. Fameli).
}

consequence a significant cause for the monitored exceedances of ambient air quality limit values mainly in urban areas (EEA, 2013a). In 2011, the contribution of road transport emissions to the nitrogen oxide (NOx) and monoxide carbon (CO) in Europe amounted to $40 \%$ and $26 \%$, respectively (EEA, 2013b). They are also a major source of particle emissions $\left(\mathrm{PM}_{10}\right.$ and $\left.\mathrm{PM}_{2.5}\right)$ (Pant and Harrison, 2013) and nonmethane volatile organic compounds (NMVOCs). Passenger cars (PCs) and heavy duty vehicles (HDVs) are the principal contributors to NOx emissions while, passenger cars alone are among the top five key categories for CO emissions (EEA, 2013b). Moreover, concentrations of $\mathrm{NO}_{2}$ and $\mathrm{PM}_{10}$ measured at a particular location are influenced by a variety of local and distant sources. Using source apportionment 
techniques in order to establish the contributions made by transport and other sources it was found that the EU-27 averaged contribution of urban and local traffic to $\mathrm{PM}_{10}$ concentration was 34\% in 2010 (measured at 29 urban traffic sites) (EEA, 2012).

In this framework the European Union set out legislations towards cleaner engine technologies and fuels which have positively affected emissions from road traffic (Colvile et al., 2001; Zamboni et al., 2009). As a consequence, total emissions in EU-27 have dropped considerably (reference period 1990-2011) including emissions of the three air pollutants primarily responsible for the formation of ground-level $\mathrm{O}_{3}$ : $\mathrm{CO}(64 \%$ reduction in the EU-27, 57\% for Greece), NMVOC (59\% reduction in the EU-27, 41\% for Greece) and NOx (48\% reduction in the EU-27, 9\% for Greece) (EEA, 2013b). Regarding NOx, the emission reductions from the road transport sector have primarily been achieved as a result of fitting catalysts to vehicles (driven by the legislative 'Euro' standards) (EEA, 2012). As far as Greece is concerned, the road transport share on national pollutant emissions for 2010 was about $60 \%, 32 \%, 21 \%$ and $7 \%$ for CO, NOx, NMVOC and $\mathrm{PM}_{2.5}$, respectively (Table 1 ). Therefore, studying accurately vehicles' emissions can enrich our knowledge towards the formulation of efficient air quality management schemes (Tsilingiridis et al., 2002; Giannouli et al., 2011), since the emission inventory is a key component of any air pollution control programme (Souza et al., 2013).

The first comprehensive emission inventory for the road transport sector for Greece was developed by Symeonidis et al., 2003 with the use of COPERT (Computer Programme to Calculate Emissions from Road Transport) II covering the period 1992-2000 and revealed the effects from the import of new catalyst cars in the Greek market. A spatially $\left(10 \times 10 \mathrm{~km}^{2}\right)$ and temporally (1-hour) disaggregated anthropogenic emission inventory of ozone precursors (NOx, NMVOC and $\mathrm{CO}$ ) for the southern Balkan region (including the Greek territory) was implemented by Poupkou et al. (2007) adopting 2000 as a reference year. Markakis et al. (2010) constructed an emission inventory for Greece for the year 2003 in a $10 \times 10 \mathrm{~km}^{2}$ spatial and 1-hour temporal resolution respectively. Concerning road transport emissions, two different approaches were employed, the bottom-up approach that uses activity data like traffic loads and driving speeds based on real circulation conditions and the top-down approach that uses statistical information like fleet composition and fuel consumption. For the bottom-up approach the data were assembled in the year 1998 in the framework of the "Environmental Inventory System for Transport" (EIST) project (Symeonidis et al., 2003) and consisted of hourly traffic loads and vehicle speeds for seven vehicle categories (passenger cars, taxis, light duty vehicles, heavy duty vehicles, urban buses, coaches and motorcycles) in 700 road segments of the national road network of Greece, 1001 road segments in Athens and 1710 road segments in the city of Thessaloniki. The traffic loads refer to a typical weekday and do not provide further temporal information besides the hourly variation. For the top-down approach data representing the circulating fleet in Greece and the two urban centres (Athens and Thessaloniki) per vehicle type and engine technology as well as the annual fuel consumption of gasoline and diesel, were also assembled within the EIST project for the year 1998. The traffic counts were updated in order to be representative for the year 2003 with the use of fleet growth factors (per vehicle type and engine technology) based on fleet projections (Kyriakis et al., 1998). Moreover, Greece being a party of the Long-Range Transboundary Air Pollution (LRTAP) Convention officially submits national emission data every year to the European Monitoring and Evaluation Programme (EMEP)

\section{Table 1}

National total emissions (Gg) and emissions from road transport (Gg) for the year 2010 for Greece (as reported to CLRTAP in 2012 - WebDab - EMEP database).

\begin{tabular}{lllcc}
\hline 2010 & CO & NOx & NMVOC & $\mathrm{PM}_{2.5}$ \\
\hline National total & 526.53 & 321.62 & 184.38 & 62.81 \\
Road transport & 317.78 & 103.56 & 39.09 & 4.40 \\
\% contribution to total emissions & $(60.35 \%)$ & $(32.20 \%)$ & $(21.20 \%)$ & $(7.00 \%)$ \\
\hline
\end{tabular}

via the United Nations Economic Commission for Europe (UNECE), on a $50 \times 50 \mathrm{~km}^{2}$ spatial resolution that are freely available online at www.ceip.at. Aleksandropoulou and Lazaridis (2004) performed a spatial distribution based on the annual national data mentioned above and developed an emission inventory for Greece $\left(5 \times 5 \mathrm{~km}^{2}\right)$ from anthropogenic and natural sources. The spatial resolution was increased based on the allocation of emissions from several sources, the land use and population density data. Since an accurate and reliable emission inventory was missing, Progiou and Ziomas (2012) presented a twentyyear road traffic emission trend for Greece. In this work, annual emissions of air pollutants from road transport in Greece were calculated for the period 1990-2009 without being further temporally and spatially analysed. They found that the age of the vehicles and the corresponding engine technology are the critical parameters in determining the amount of pollutants emitted from both passenger cars and heavy duty vehicles demonstrating the importance of a renewal programme of the old circulating vehicles in order to set an effective air pollution abatement strategy.

The Attica region was chosen by many researchers for further study since it is the most populated area in Greece, hosting 4.2 million habitants, about $36 \%$ of the total Greek population (http://epp.eurostat.ec. europa.eu/) (Fig. 1). The Athens basin is located near irregular coastline at the centre of Attica and is surrounded by moderately high mountains from the west, north and east. The complex topography in combination with the concentration of anthropogenic activities (road traffic, residential heating, industrial and shipping emissions) and local meteorological conditions have often led to the development of air pollution episodes (Kassomenos et al., 2006; Bossioli et al., 2007; Hatzianastassiou et al., 2007; Grivas et al., 2008; Kassomenos et al., 2012; Kalabokas et al., 2012; Pateraki et al., 2013).

Recognising the need to understand the processes that lead to air pollution episodes in order to manage the air quality effectively, researchers performed early photochemical simulations above the Athens basin (Pilinis et al., 1993). However, the traffic emissions used were mere approximations and were not spatially and temporally analysed thus leading to inaccuracies. In this respect several early efforts to construct emission inventories for Athens were made by Economopoulos (1997) who produced total values of smoke, sulfur dioxide $\left(\mathrm{SO}_{2}\right), \mathrm{NO}_{\mathrm{x}}$, $\mathrm{CO}$, and volatile organic compound (VOC) based on approximate data from space heating boilers and traffic for the centre and the periphery of Athens. His research revealed a decrease in NOx emissions from internal combustion activities (vehicle emissions) from 22.571 tonnes in 1989 (total year-average) to 21.605 tonnes in 1992 (total yearaverage). Ziomas et al. (1998) constructed an emission inventory for selected dates in 1994 including only $\mathrm{NO}_{\mathrm{x}}, \mathrm{CO}$, and VOC for Athens using aircraft and ground measurement data as a basis. Similarly, Kourtidis et al. (1999) produced a traffic emission inventory for a selected day in 1994, based on measurements from a typical street of Athens. Both researchers provided insight on the emission control strategies related to VOC control and VOC speciation in order to reduce ozone $\left(\mathrm{O}_{3}\right)$.

An emission inventory for Athens was implemented by Markakis et al. (2010) on a $2 \times 2 \mathrm{~km}^{2}$ spatial and 1-hour temporal resolution for the year 2003. The share of the road transport emissions to the total emissions was found to be significantly higher in Athens compared with smaller cities. Passenger cars and motorcycles were a considerable contributor to CO and NMVOC emissions whereas heavier vehicles (buses, coaches and HDVs) were responsible for the majority of NOx emissions. With the use of emission data from the United Nations Environment Programme (UNEP)/EMEP $\left(50 \times 50 \mathrm{~km}^{2}\right.$ resolution), Aleksandropoulou et al. (2011) developed an emission inventory for the Greater Athens Area (2007 being the reference year, $1 \times 1 \mathrm{~km}^{2}$ ) indicating the importance of road transport to CO, NMVOC and NOX emissions. Annual road traffic emissions for the Greater Athens Area were also calculated by Progiou and Ziomas (2011) for the period 1990-2009 while the relationship with air pollutant concentrations was also investigated. PCs were found to be the major contributors to 


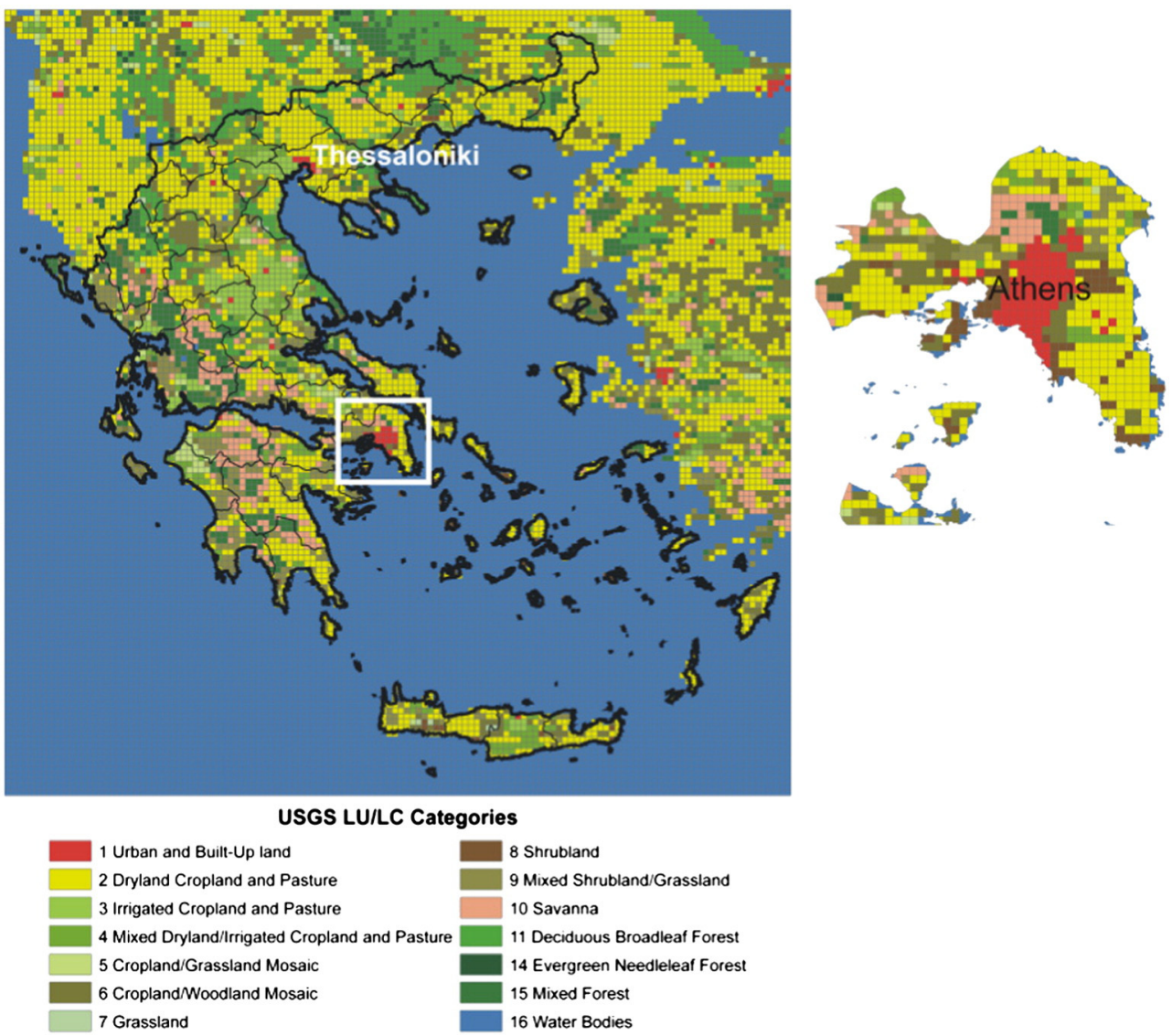

Fig. 1. Greece (Grid 1 - left and marked with a black line) and Attica (Grid 2 - right and marked with a white square in Grid 1) with the land use categories attributed at each cell.

CO, NMVOC and methane $\left(\mathrm{CH}_{4}\right)$ emissions while HDVs were associated with $\mathrm{PM}_{10}$ and NOx emissions. However, the annual emissions were neither spatially allocated in gridded form nor temporarily resolved in hourly values.

Since road transport is a large contributor to urban air pollution, while it accounts for approximately $25 \%$ of the $\mathrm{CO}_{2}$ emissions responsible for climate change (EEA, 2013d), many countries have encouraged a shift to diesel fuelled cars in an effort to reduce greenhouse gas (GHG) emissions (Sullivan et al., 2004; Zachariadis, 2006; Zervas et al., 2006; Zervas, 2006). On the contrary, diesel fuelled cars are sources of NOx, fine particulates and $\mathrm{CO}$ and have been blamed for maintaining high pollution levels in urban areas (Gonzalez and Marrero, 2012). According to Weiss et al. (2012) the on-road NOx emissions of diesel cars appear to exceed substantially applicable emission standards and the introduction of the more stringent Euro 6 emission standards might not adequately reduce the on-road NOx emissions of new diesel cars. However, as presented by the European Automobile Manufacturer's Association (ACEA) (ACEA, 2013) most new cars in Europe have a diesel engine. According to the ACEA the percentage of diesel passenger cars among new registrations was $4.0 \%$ in 2010 for Greece which is very low compared with other European countries for the same year - 70.8\% in France, 41.9\% in Germany, $70.6 \%$ in Spain, $75.9 \%$ in Belgium, $67.1 \%$ in Portugal, $45.9 \%$ in Italy, $46.1 \%$ in UK, $50.7 \%$ in Austria, $45.7 \%$ in Denmark and $41.5 \%$ in Finland. Moreover, as shown in Fig. 2 the percentage of diesel passenger cars in use in 2010 was much higher for the European countries than for Greece (ANFAC, 2012). In this respect, the Greek authorities cancelled the ban on movement from passenger cars with diesel engines on the city centre of Athens and Thessaloniki - the two larger cities of Greece. As a result the share of diesel in new PC registrations increased to 40\% in 2011 and 58\% in 2012.
As already mentioned above, emission inventories are used as input data in photochemical models and thus it is very important that they are reliable and regularly updated with high spatial and temporal allocation data, covering a year-to-year variation (Hanna et al., 2001; Poupkou et al., 2008; Taghavi et al., 2005; Coelho et al., 2014). In order to address these requirements the most accurate and updated data must be used concerning vehicle fleet (vehicle types, engine technology and engine capacity), fuel consumption and average speeds under different road types. The emission models used for the estimation of road traffic emissions have become comprehensive enough with time in order to take into account the technological developments and the shift of research activities to certain pollutants (Kousoulidou et al., 2013). Moreover, it is very important for the emission inventory to be evaluated in order

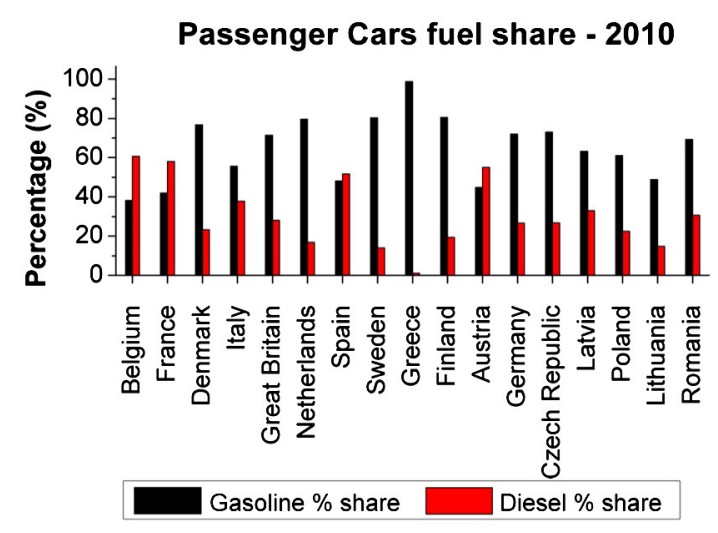

Fig. 2. Percentage (\%) of passenger cars in use by fuel type consumption for European countries on 2010 (ANFAC, 2012). 
to ensure that it properly represents real conditions (Winiwarter et al., 2003). Especially the road traffic contribution must be correctly assessed to a comprehensive emission inventory and this can be possible with the continuous validation of the road traffic emission models (Smit et al., 2010; Noland and Quddus, 2006; Zachariadis and Samaras, 1997). Within that frame, the purpose of the present work is to a) construct an emission inventory in order to examine the road traffic emission trend in Greece and the Attica for the period 2006-2010 on a spatial scale of $6 \times 6 \mathrm{~km}^{2}$ and $2 \times 2 \mathrm{~km}^{2}$ respectively and on a temporal scale of $1 \mathrm{~h}, \mathrm{~b}$ ) estimate the possible benefits of increased diesel penetration where part of gasoline passenger cars are replaced by diesel ones in the Attica and c) perform a sensitivity analysis of the effects on emissions from changes in various parameters such as engine type, vehicle velocity, mean trip length, and vehicle fleet.

\section{Methodology}

The road transport sector emissions were calculated using the topdown approach based on the EMEP/CORINAIR methodology (EEA, 2013b). Within that frame COPERT IV was applied for the estimation of annual emissions at a national level (Greece) and for Attica covering the period 2006-2010. COPERT is user-friendly software (Gkatzoflias et al., 2012; Katsis et al., 2012) and it is officially proposed from the United Nations Framework Convention on Climate Change (UNFCCC) (IPCC, 2006). The methodology allows the estimation of emissions from five main vehicle classes: passenger cars (PCs), light commercial vehicles (LCVs), heavy duty vehicles, buses and motorcycles. These are then distinguished according to the fuel type used (gasoline, diesel, liquid petroleum gas, compressed natural gas), the EU Directives to which they conform in terms of emissions (PRE ECE, ECE 15/00-01, Euro 1, Euro 2, etc.) and the engine capacity (e.g. $<1.41 \mathrm{lt}, 1.4-2.0 \mathrm{lt}$, and $>2.01$ for passenger cars, $<3.5 \mathrm{t}$ or $>3.5 \mathrm{t}$ for commercial vehicles).

\subsection{Model description}

Generally total emissions are calculated by means of the following equation, for each vehicle category (EEA, 2013c):

$\mathrm{E}_{\text {total }}=\mathrm{E}_{\text {hot }}+\mathrm{E}_{\text {cold }}$

where $E_{\text {total }}$ is the annual total emissions ( $g$ ) of any pollutant for Greece and Attica, $E_{\text {hot }}$ is the emissions ( $g$ ) during stabilised (hot) engine operation and $\mathrm{E}_{\text {cold }}$ is the emissions ( $\mathrm{g}$ ) during transient thermal engine operation (cold start).

Since engine operation determines vehicle emissions a distinction was made between urban, rural and highway driving conditions (e.g. for gasoline PCs the share was considered to be $44 \%, 42 \%$ and $14 \%$ for urban, rural and highway driving conditions respectively). Moreover, different speed values were attributed to vehicle categories for each driving condition (e.g. for PCs $19 \mathrm{~km} / \mathrm{h}, 60 \mathrm{~km} / \mathrm{h}$ and $90 \mathrm{~km} / \mathrm{h}$ correspond to the urban, rural and highway driving conditions). The necessary activity data (share of driving condition and mean travelling speeds in different driving conditions) as well as the information needed for vehicle technology splitting were collected by Ntziachristos et al. (2008) and are provided by Emisia SA for Greece (www.emisia.com).

Road traffic emissions depend on: 1) the distance traveled ( $\mathrm{km})$; 2 ) the fuel used (e.g. diesel, gasoline); 3 ) the velocity ( $\mathrm{km} / \mathrm{h}$ ) or road type; 4 ) the engine capacity and 5) the emission standards (e.g. Euro 4). Therefore, the formula to be applied for the calculation of hot emissions of pollutants yields:

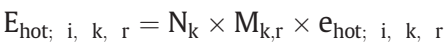

where $E_{\text {hot; } i, k, r}$ is the annual hot exhaust emissions of the pollutant $i$ (g), produced by vehicles of technology $k$ driven on roads of type $r, N_{k}$ is the number of vehicles (veh) of technology $\mathrm{k}$ in operation in the period concerned, $M_{k, r}$ is the mileage per vehicle ( $\mathrm{km} / \mathrm{veh}$ ) driven on roads of type $r$ by vehicles of technology $\mathrm{k}$ and $\mathrm{e}_{\mathrm{hot} ; \mathrm{i}, \mathrm{k}, \mathrm{r}}$ is the emission factor in $(\mathrm{g} / \mathrm{km})$ for pollutant $\mathrm{i}$, relevant for the vehicle technology $\mathrm{k}$, operated on roads of type $r$.

Cold-start emissions are attributed mainly to urban driving (and secondarily to rural driving), as it is expected that a limited number of trips start at highway conditions. Cold-start emissions are introduced into the calculation as additional emissions per $\mathrm{km}$ using the following formula:

$\mathrm{E}_{\text {cold; } \mathrm{i}, \mathrm{k}}=\beta_{\mathrm{i}, \mathrm{k}} \times \mathrm{N}_{\mathrm{k}} \times \mathrm{M}_{\mathrm{k}} \times \mathrm{e}_{\text {hot; }} \mathrm{i}, \mathrm{k} \times\left(\mathrm{e}^{\text {cold }} /\left.\mathrm{e}^{\text {hot }}\right|_{\mathrm{i}, \mathrm{k}}-1\right)$,

where $E_{\text {cold; } i, k}$ is the cold-start emissions of pollutant $i$ (for the reference year), produced by vehicle technology $k, \beta_{i, k}$ is the fraction of mileage driven with a cold engine or the catalyst operated below the lightoff temperature for pollutant $i$ and vehicle technology $k, N_{k}$ is the number of vehicles (veh) of technology $\mathrm{k}$ in circulation, $\mathrm{M}_{\mathrm{k}}$ is the total mileage per vehicle $(\mathrm{km} / \mathrm{veh})$ in vehicle technology $\mathrm{k}$ and $\mathrm{e}^{\text {cold }} /\left.\mathrm{e}^{\mathrm{hot}}\right|_{\mathrm{i}, \mathrm{k}}$ is the cold/hot emission quotient for pollutant $\mathrm{i}$ and vehicles of $\mathrm{k}$ technology. The $\beta$-parameter depends upon ambient temperature $t_{a}$ (for practical reasons the average monthly temperature can be used), and the pattern of vehicle use - in particular the average trip length $l_{\text {trip }}$. A value of $12.4 \mathrm{~km}$ has been established for the $1_{\text {trip }}$ value.

\subsection{Description of input data and model output}

Table 2 presents the input data required for the COPERT run. Detailed fleet composition data were provided by the Greek Ministry of Transport for the year 2006 for Greece. In order to construct the annual fleet for the period 2007-2010 for Greece new vehicle registrations were obtained from ACEA, the Association of Motor Vehicle Importers Representatives (AMVIR), the National Statistical Service of Greece and the International Council on Clean Transportation (ICCT, 2011). Regarding the development of the vehicle fleet for Attica for the whole period (2006-2010) statistical data from the Eurostat Database were used. The yearly fleet composition at national level is reported in Table 3 and for Attica in Table 4, while the passenger cars' speciation per fuel type for both Greece and Attica is presented in Fig. 3. The Hellenic National Meteorological Service provided the necessary minimum and maximum monthly temperature profiles for the calculation of the monthly mean temperature values required by COPERT (Table 5). The annual total fuel consumption for each fuel type wasprovided by the Greek Ministry of the Environment (Fig. 4). The annual mileage was calculated based on methodology proposed by Symeonidis

Table 2

Input data used in the inventory and the sources that provided these data.

\begin{tabular}{ll}
\hline Input data & Source \\
\hline $\begin{array}{l}\text { Vehicle fleet composition per vehicle type, } \\
\text { cylinder capacity and fuel type }\end{array}$ & Greek Ministry of Transport for the \\
New vehicle registrations & year 2006 \\
& European Automobile Manufacturers \\
& (ACEA) \\
& Association of Motor Vehicle \\
& Importers Representatives (AMVIR) \\
& National Statistical Service of Greece \\
& International Council on Clean Trans- \\
& portation (ICCT, 2011) \\
& Hellenic National Meteorological \\
Minimum and maximum monthly mean & Service \\
temperature profiles & Ministry of the Environment, Energy \\
Annual fuel consumption & and Climate Change \\
Road network & OpenStreetMap contributors \\
Traffic counts & Hellenic Institute of Transport (H.I.T.) \\
& Attica Traffic Management Centre \\
Population data & Eurostat (GEOSTAT population grid) \\
\hline
\end{tabular}


Table 3

Temporal variation of the vehicle fleet composition in Greece.

\begin{tabular}{|c|c|c|c|c|c|c|}
\hline Vehicle category & 2006 & 2007 & 2008 & 2009 & 2010 & $2010 \%$ contribution \\
\hline PCs & $4,613,207$ & $4,801,453$ & $5,019,133$ & $5,134,955$ & $5,221,868$ & 64.74 \\
\hline LCVs & 991,234 & $1,016,906$ & $1,040,892$ & $1,046,397$ & $1,056,963$ & 13.10 \\
\hline HDVs & 228,555 & 238,939 & 248,466 & 255,866 & 261,170 & 3.24 \\
\hline Buses & 26,938 & 27,102 & 27,186 & 27,324 & 27,311 & 0.34 \\
\hline Motorcycles & $1,179,719$ & $1,295,217$ & $1,388,607$ & $1,448,851$ & $1,499,133$ & 18.58 \\
\hline Total & $7,039,653$ & $7,379,617$ & $7,724,284$ & $7,913,393$ & $8,066,445$ & 100.00 \\
\hline
\end{tabular}

et al. (2003). According to this study old vehicles travel fewer kilometres.

The emission estimation methodology covers exhaust emissions of CO, NOx, NMVOC, $\mathrm{CH}_{4}, \mathrm{CO}_{2}, \mathrm{~N}_{2} \mathrm{O}, \mathrm{NH}_{3}$, SOx, exhaust PM, PAHs and POPs, dioxins and furans, and heavy metals contained in the fuel (lead, arsenic, cadmium, copper, chromium, mercury, nickel, selenium and zinc). NOx emissions are further split into $\mathrm{NO}$ and $\mathrm{NO}_{2}$. $\mathrm{PM}$ is also divided into elemental carbon and organic carbon as a function of vehicle technology. A detailed speciation of NMVOCs is also provided, and this covers homologous series such as alkanes, alkenes, alkynes, aldehydes, ketones and aromatic compounds. PM mass emissions in vehicle exhaust mainly fall in the $\mathrm{PM}_{2.5}$ size range. Therefore, all PM mass emission factors are assumed to correspond to $\mathrm{PM}_{2.5}$.

\subsection{Spatial and temporal allocation of annual emissions}

The annual emissions calculated by COPERT IV for each driving condition (urban, rural, highways) were spatially allocated on a $6 \mathrm{~km}$ resolution grid over Greece (Grid 1) and a $2 \mathrm{~km}$ resolution grid over Attica (Grid 2) with the use of a Geographic Information System (GIS). The above grids were constructed in Lambert Conformal Conic coordinate system. Fig. 1 presents Grids 1 and 2 as well as the land use categories attributed to each cell (Fameli et al., 2013).

According to the EMEP/EEA Air Pollutant Emission Inventory Guidebook (EEA, 2013b) the aggregated emission inventory can be spatially resolved with the use of surrogate datasets. The annual emissions were allocated to the Greek road network based on the three driving conditions (urban, rural, highways) used by COPERT. For this purpose digital road maps were used (OpenStreetMap data, 2012) and road types were classified into 3 categories: a) urban roads, b) primary and secondary roads and c) highways. Therefore, urban emissions were distributed to urban areas only based on population data provided by the GEOSTAT population grid (Eurostat, 2012) and according to the equation:

$\mathrm{E}_{\mathrm{i}, \mathrm{x}}=\mathrm{E}_{\mathrm{i}} \frac{\text { pop }, \mathrm{x}_{\text {}}}{\text { pop,tot }_{\text {tot }}}$

where $E_{i, x}$ is the emission of pollutant $i$ in the cell $x, E_{i}$ is the annual total emission of pollutant $\mathrm{i}, \mathrm{pop}_{, \mathrm{x}}$ is the population in the cell $\mathrm{x}$, and pop,tot ${ }_{\text {, }}$ the total population for the reference grid (Greece or Attica).

Concerning rural emissions they were spread across the grid at primary and secondary roads according to the total length of the road per grid cell. Highway emissions were allocated to highways only based on mean daily traffic flow data provided by the Hellenic Institute of Transport (H.I.T.) covering the national highways.
The next step included the temporal disaggregation of the gridded annual emissions to monthly, weekly and diurnal values based on the equation:

$\mathrm{E}_{\mathrm{h}, \mathrm{i}, \mathrm{x}}=\mathrm{E}_{\mathrm{i}, \mathrm{x}} \times \mathrm{M}_{\mathrm{i}} \times \mathrm{D}_{\mathrm{i}} \times \mathrm{H}_{\mathrm{i}}$,

where $E_{h, i}$ is the hourly emissions of pollutant $i$ in the cell $x, E_{i, x}$ is the annual emissions of pollutant $\mathrm{i}$ in the cell $\mathrm{x}$ and $\mathrm{M}, \mathrm{D}$ and $\mathrm{H}$ are the monthly, daily and hourly disintegration coefficients, respectively. For the development of temporal coefficients for Grid 2 hourly traffic counts were provided by the Attica Traffic Management Center for the period 2006-2010 covering the main road network of the GAA at both directions. As a consequence the yearly, monthly, daily and hourly profiles were created highlighting the special characteristics of the GAA traffic.

\subsection{Impacts of input parameters on Attica emissions}

In order to estimate the effects of different input parameters on emissions calculated by COPERT for the Attica region seven scenarios were constructed concerning the fleet of PCs and HDVs, the driving condition share, the velocity, the length of the trip and the maximum and minimum monthly temperatures (Table 6). The influence of vehicles with Euro latest standards was also verified. The reference year for the scenario process was 2010 so changes were made only for that year's inputs resulting in different sub-scenarios named as 2010_1, 2010_2, etc. More specifically, the seven scenarios with their sub-scenarios were:

* Scenario A - dieselisation. In order to estimate the possible benefits due to the increased diesel penetration on PCs, three sub-scenarios were constructed where part of gasoline passenger cars was replaced by diesel ones. The PC fleet changed following the trends in gas/diesel PC ratio of different European countries as presented by the ANFAC (2012) (Fig. 2). Since only Euro 5 diesel PCs are allowed to enter the Athens city centre the replacement regards only this type of engine technology for diesel PC (Fig. 5). Concerning the engine capacity the category 1.4-2.0lt was selected since it represents the average engine capacity among new $\mathrm{PC}$ registrations in Greece (ACEA, http://www.acea.be/statistics). The other vehicles (LCVs, HDVs, buses, motorcycles) remained unchanged. The three sub-scenarios were:

$>$ 2010_1: 20\% of total passenger cars were considered to be diesel Euro 5 vehicles with engine capacity $1.4-2.01$ t.

$>$ 2010_2: 30\% of total passenger cars were considered to be diesel Euro 5 vehicles with engine capacity $1.4-2.01$ t.

$>$ 2010_3: 60\% of total passenger cars were considered to be diesel Euro 5 vehicles with engine capacity $1.4-2.01$ t.

Table 4

Temporal variation of the vehicle fleet composition in Attica.

\begin{tabular}{|c|c|c|c|c|c|c|}
\hline Vehicle category & 2006 & 2007 & 2008 & 2009 & 2010 & $2010 \%$ contribution \\
\hline PCs & $2,393,379$ & $2,526,432$ & $2,643,889$ & $2,712,217$ & $2,753,705$ & 74.09 \\
\hline LCVs & 212,581 & 218,087 & 221,501 & 225,301 & 224,886 & 6.05 \\
\hline HDVs & 49,016 & 51,243 & 52,872 & 55,093 & 55,565 & 1.49 \\
\hline Buses & 12,970 & 12,584 & 13,088 & 12,688 & 12,681 & 0.34 \\
\hline Motorcycles & 593,354 & 586,287 & 621,822 & 647,933 & 670,060 & 18.03 \\
\hline Total & $3,261,300$ & $3,394,633$ & $3,553,172$ & $3,653,232$ & $3,716,897$ & 100.00 \\
\hline
\end{tabular}



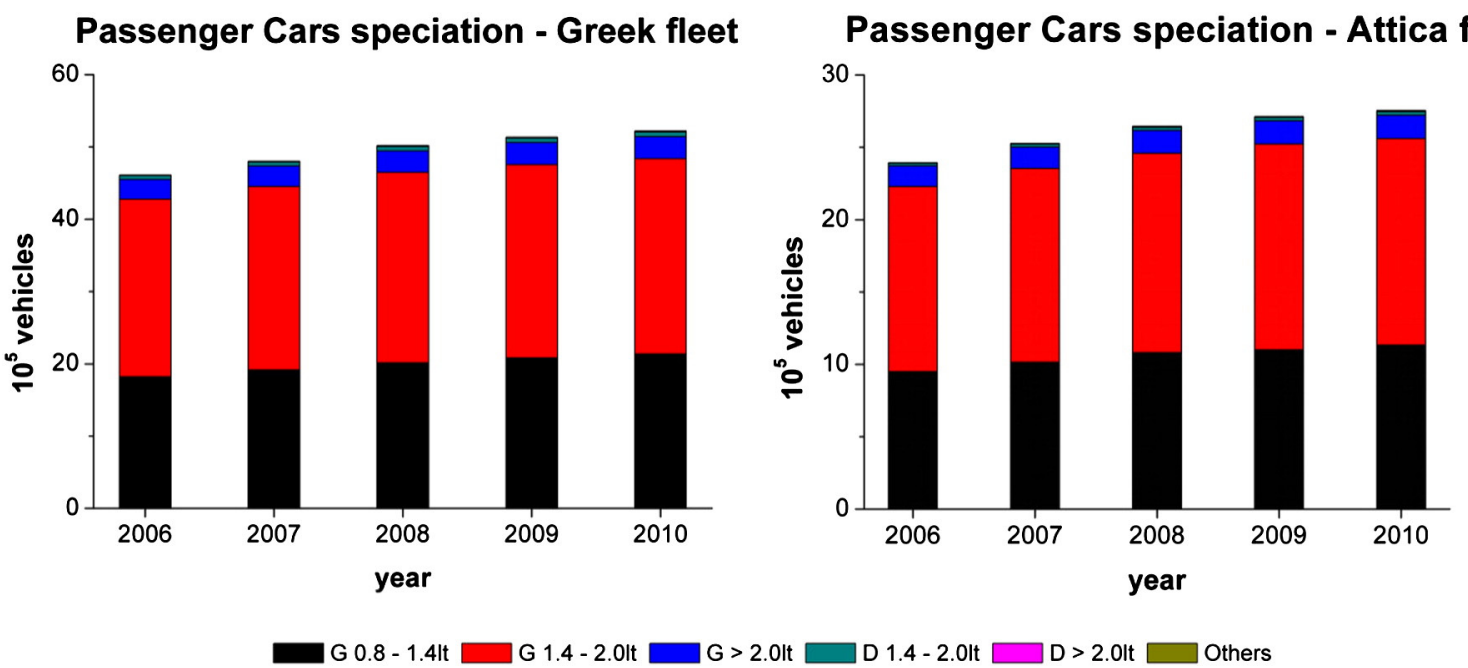

Fig. 3. Passenger car speciation according to fuel use for Greece (left) and Attica (right) ( $G=$ gasoline, $D=$ diesel).

* Scenario B - HDV fleet. The HDV fleet effect on emissions was estimated by increasing and decreasing the number of HDVS as following:

$>$ 2010_1,2010_4: the HDV fleet increased/decreased by $5 \%$.

$>$ 2010_2, 2010_5: the HDV fleet increased/decreased by $10 \%$.

$>$ 2010_3, 2010_6: the HDV fleet increased/decreased by $20 \%$.

* Scenario C - Driving condition share. Since the urban road network prevails among the rural roads and highways in the Attica region the driving condition share for PCs and motorcycles changed and three sub-scenarios were constructed favouring the urban driving condition share as shown in Table 6

* Scenario D - Velocity. The mean travelling velocity of each driving condition increased for different vehicle categories as shown in Table 6. The speed limits for Greece were used in sub-scenario 2010_3. Hourly velocity values were provided from the Attica Traffic Management Center for the development of the mean urban $(32.98 \mathrm{~km} / \mathrm{h})$, rural $(66.97 \mathrm{~km} / \mathrm{h})$ and urban $(79.78 \mathrm{~km} / \mathrm{h})$ velocities for sub-scenario: 2010_4.

* Scenario E - mean trip length. The European value proposed by Emisia SA (www.emisia.com) for the average distance travelled by a trip of passenger cars is $12.4 \mathrm{~km}$ (Ntziachristos and Samaras, 2010). Six sub-scenarios were developed by increasing/decreasing the trip length on a $2 \mathrm{~km}$ step (Table 6).

* Scenario F - Temperature. The average monthly minimum and maximum temperatures changed by $5 \%, 10 \%$ and $20 \%$ in order to analyse the sensitivity of calculations with respect to the temperature.

Table 5

Monthly mean temperature values used in COPERT.

\begin{tabular}{lcc}
\hline Month & $\begin{array}{l}\text { Mean minimum } \\
\text { temperature }\left({ }^{\circ} \mathrm{C}\right)\end{array}$ & $\begin{array}{l}\text { Mean maximum } \\
\text { temperature }\left({ }^{\circ} \mathrm{C}\right)\end{array}$ \\
\hline January & 3.89 & 9.81 \\
February & 5.68 & 12.54 \\
March & 7.79 & 15.39 \\
April & 11.21 & 19.47 \\
May & 14.10 & 24.65 \\
June & 18.52 & 28.37 \\
July & 20.79 & 29.17 \\
August & 21.89 & 32.28 \\
September & 17.92 & 26.47 \\
October & 14.84 & 21.45 \\
November & 8.51 & 16.31 \\
December & 6.55 & 13.13 \\
\hline
\end{tabular}

* Scenario G - Euro standards. The influence of the latest Euro standards on emissions was examined with the development of two sub-scenarios.

$>$ 2010_1: Pre-Euro PCs were reduced by $20 \%$ and the number of vehicles was added to Euro 5 PCs.

$>$ 2010_2: 2010_1 plus Euro 1 and Euro 2 PCs were reduced by $20 \%$ and the number of vehicles was added to Euro 5 PCs.

$>$ 2010_3: 2010_2 plus Euro 3 PCs were reduced by 20\% and the number of vehicles was added to Euro 5 PCs.

\section{Results and discussion}

\subsection{Annual total emissions for Greece and Attica}

The annual total emission variation for the period 2006-2010 is presented in Fig. 6 for Greece and Attica. The decrease in gasoline consumption in 2008 and 2010 and the subsequent reduction of annual mileage driven affected the CO, VOC and NMVOC emissions. The percentage decrease for Greece from 2006 to 2008 was $9.5 \%$ for CO, 7.3\% for VOC and 7.7\% for NMVOC while for the period 2006-2010 the decrease was $32.8 \%, 24.0 \%$ and $24.3 \%$, respectively. Moreover, the import of new anti-pollution technology engines (Euro 4 became effective in 2005 and Euro 5 in 2009) affected the CO, VOC and NMVOC emissions since the penetration of vehicles with Euro latest standards continuously increased among total fleet. The $\mathrm{CO}_{2}$ emissions were

Fuel consumption in Greece from the road transport sector

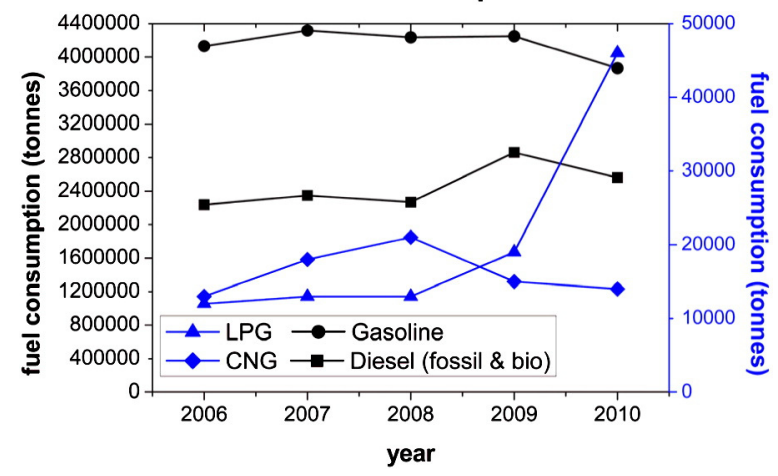

Fig. 4. Fuel consumption in Greece from the road transport sector as used in COPERT input data ( $\mathrm{LPG}=$ liquid petroleum gas, $\mathrm{CNG}=$ compressed natural gas). 
Table 6

Scenarios for the estimation of the effects of different input COPERT parameters on Attica emissions.

\begin{tabular}{|c|c|c|c|c|c|c|c|c|c|}
\hline Scenario & Factor & & 2010 & 2010_1 & 2010_2 & 2010_3 & 2010_4 & 2010_5 & 2010_6 \\
\hline A & PC fleet & & & $20 \%$ & $30 \%$ & $60 \%$ & & & \\
\hline B & HDV fleet & & & $-5 \%$ & $-10 \%$ & $-20 \%$ & $5 \%$ & $10 \%$ & $20 \%$ \\
\hline \multirow[t]{6}{*}{ C } & Driving condition share & $P C^{\mathrm{a}}-\mathrm{U}$ & 42 & $\mathrm{U}: 50$ & U:60 & U:70 & & & \\
\hline & & $\mathrm{R}$ & 44 & $\mathrm{R}: 40$ & $\mathrm{R}: 30$ & $\mathrm{R}: 20$ & & & \\
\hline & & $\mathrm{H}$ & 14 & $\mathrm{H}: 10$ & $\mathrm{H}: 10$ & $\mathrm{H}: 10$ & & & \\
\hline & & Motorcycles $^{\mathrm{a}}-\mathrm{U}$ & 65 & $\mathrm{U}: 70$ & $\mathrm{U}: 80$ & $\mathrm{U}: 80$ & & & \\
\hline & & $\mathrm{R}$ & 20 & $\mathrm{R}: 15$ & $\mathrm{R}: 10$ & $\mathrm{R}: 10$ & & & \\
\hline & & $\mathrm{H}$ & 15 & $\mathrm{H}: 10$ & $\mathrm{H}: 10$ & $\mathrm{H}: 10$ & & & \\
\hline \multirow[t]{9}{*}{ D } & Velocity $(\mathrm{km} / \mathrm{h})$ & $P C^{\mathrm{a}}-\mathrm{U}$ & 19 & 30 & 40 & 50 & 32.98 & & \\
\hline & & $\mathrm{R}$ & 60 & 70 & 80 & 90 & 66.97 & & \\
\hline & & $\mathrm{H}$ & 90 & 100 & 100 & 110 & 79.78 & & \\
\hline & & Motorcycles $^{\mathrm{a}}-\mathrm{U}$ & 30 & 30 & 40 & 50 & 32.98 & & \\
\hline & & $\mathrm{R}$ & 60 & 70 & 80 & 90 & 66.97 & & \\
\hline & & $\mathrm{H}$ & 70 & 100 & 100 & 110 & 79.78 & & \\
\hline & & HDVs & 30 & 30 & 40 & 50 & 32.98 & & \\
\hline & & & & 70 & 80 & 80 & 66.97 & & \\
\hline & & & & 90 & 90 & 90 & 79.78 & & \\
\hline $\mathrm{E}$ & ltrip (km) & & 12.4 & 6.4 & 8.4 & 10.4 & 14.4 & 16.4 & 18.4 \\
\hline $\mathrm{F}$ & Temp & & & $-5 \%$ & $-10 \%$ & $-20 \%$ & $5 \%$ & $10 \%$ & $20 \%$ \\
\hline G & Euro standards & & & $\begin{array}{l}\text { Pre-Euro } \\
-20 \%\end{array}$ & $\begin{array}{l}\text { 2010_1 \& Euro } 1+2 \\
-20 \%\end{array}$ & $\begin{array}{l}\text { 2010_2 \&Euro } 3 \\
-20 \%\end{array}$ & & & \\
\hline
\end{tabular}

a $\mathrm{U}=$ urban, $\mathrm{R}=$ rural and $\mathrm{H}=$ highways.

related to the annual fuel consumption (Fig. 4) presenting an increase for the first 2 years (2006-2007) while inform 2009 to 2010 a decrease of $6.5 \%$ was observed for Greece coupled with an $8.9 \%$ reduction in gasoline consumption and $10.5 \%$ in diesel consumption. However, the NOx and PM values remained rather stable presenting only a slight decrease in the period 2008-2010 in Greece and Attica, 4\% and 7\% for NOx; and $3 \%$ and $4 \%$ for particulates, respectively due to the increase in diesel vehicle fleet.

Comparing the national with the Attica emission results it is revealed that about $40 \%$ of $\mathrm{CO}_{2}, \mathrm{CO}$, VOC and NMVOC and $30 \%$ of NOx and PM are emitted in Attica. This difference is due to the fact that half of the national PC fleet (52.8\% in 2010) is located in Attica corresponding to $74 \%$ of the local fleet (Tables 3 and 4 ). The type of fuel used by this group is mainly gasoline, enriching in this way CO, VOC and NMVOC emissions (BanWeiss et al., 2008) while diesel vehicles contribute mostly to NOx and PM. In Greece most PCs, motorcycles as well as part of LCVs use gasoline fuel while HDVs, buses, taxis and the rest of LCVs use diesel fuel.

Concerning the emission distribution according to the driving condition in Attica, urban emissions prevail among rural and highways for all pollutants, as expected since the kilometres driven on urban roads were

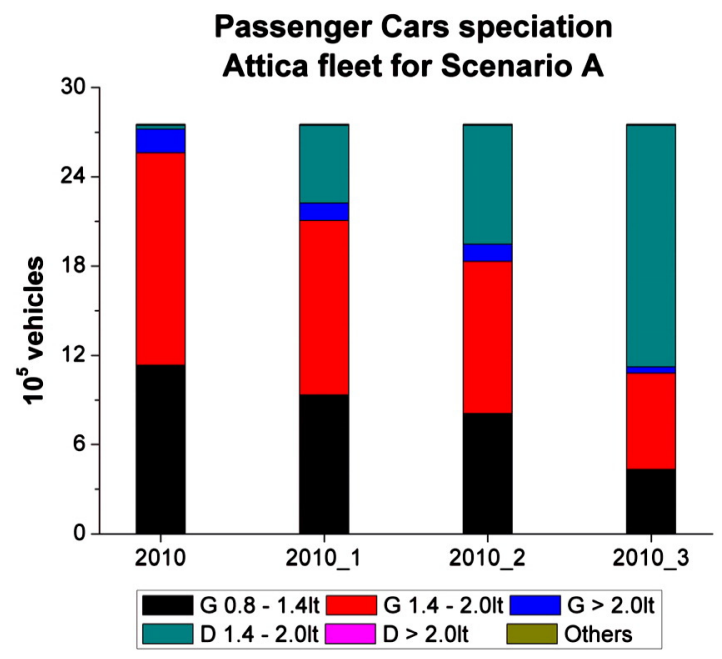

Fig. 5. Passenger car penetration fleet in Attica for the dieselisation process ( $G=$ gasoline, $\mathrm{D}=$ diesel). favoured among rural roads and highways especially for PC. Urban emissions correspond to low driving speed conditions $(19 \mathrm{~km} / \mathrm{h})$ at which engines consume more fuel. On the other hand, $\mathrm{PM}_{10}$ and $\mathrm{NO}_{\mathrm{x}}$ present an increased share in rural and highway categories (Fig. 7). The doubling of PM and NOx percentage in rural and highways stands for the travelling of HDVs and part of LCVs. However, according to Vanhulsel et al. (2014) in Belgium in 2010 the 37\% of the kilometres is travelled on highways, $41 \%$ on rural roads and $22 \%$ on urban roads. The urban share of mileage (in \%) driven by the various vehicle categories as used in TRENDS is presented by Mellios et al. (2006) for various countries indicating the special national characteristics in driving share. For example the urban share for PC in UK is $46 \%$ while in Portugal is $24 \%$.

Table 7 shows the emissions per vehicle type for the year 2010 for Attica. It is obvious that PCs contribute mostly to the total road traffic emissions of $\mathrm{CO}$, VOC, NMVOC and $\mathrm{CO}_{2}$. Approximately $25 \%$ of $\mathrm{CO}$ emissions come from gasoline PCs with engine capacity 1.4-2.0lt since this group is the most populated among PCs (Fig. 3 right). As for the engine technology, Euro $3 \mathrm{PC}$ - gasoline is considered as major polluters with $11.6 \%$ for $0.8-1.41$ t and $13 \%$ for $1.4-2.0$ lt engine capacity of CO emissions (not shown here). Diesel PCs are responsible only for $0.1 \%$ of total CO emissions (not shown here). Motorcycles also play a significant role to CO, VOC and NMVOC emissions (25\%, 26.07\% and $25.52 \%$ respectively) since they are more economic and efficient and consequently very popular to use in urban Athens traffic conditions. The vehicle category that dominates in $\mathrm{NOx}, \mathrm{PM}_{2.5}$ and $\mathrm{PM}_{10}$ emissions is HDVs with $51.27 \%, 43.97 \%$ and $38.13 \%$ respectively for 2010 (Table 7 ), which is attributed to the diesel engines. The second larger contributor to this group of pollutants comes from PCs, namely $21.3 \%$ for NOx, $27.31 \%$ for $\mathrm{PM}_{2.5}$ and $35.5 \%$ for $\mathrm{PM}_{10}$. Motorcycles have a small contribution to NOx (2.83\%), $\mathrm{PM}_{2.5}$ (7.88\%) and $\mathrm{PM}_{10}$ (7.31\%) emissions. LCVs use both gasoline and diesel fuel and as a consequence the emission percentages do not vary among pollutants, the percentage of $\mathrm{CO}$ is the highest, $13.39 \%$. Buses contribute to NOx by $15.33 \%$ and particle emissions $\left(8.29 \%-\mathrm{PM}_{2.5}, 7.39 \%-\mathrm{PM}_{10}\right)$.

\subsection{Ozone precursors in Attica}

High ozone concentrations have been recorded by researchers as well as the national network for monitoring atmospheric pollution. Hence study of the ozone precursors, VOC and NOx is of the outmost importance in order to control the occurrence of high levels (Ziomas 
$\mathrm{CO}_{2}$
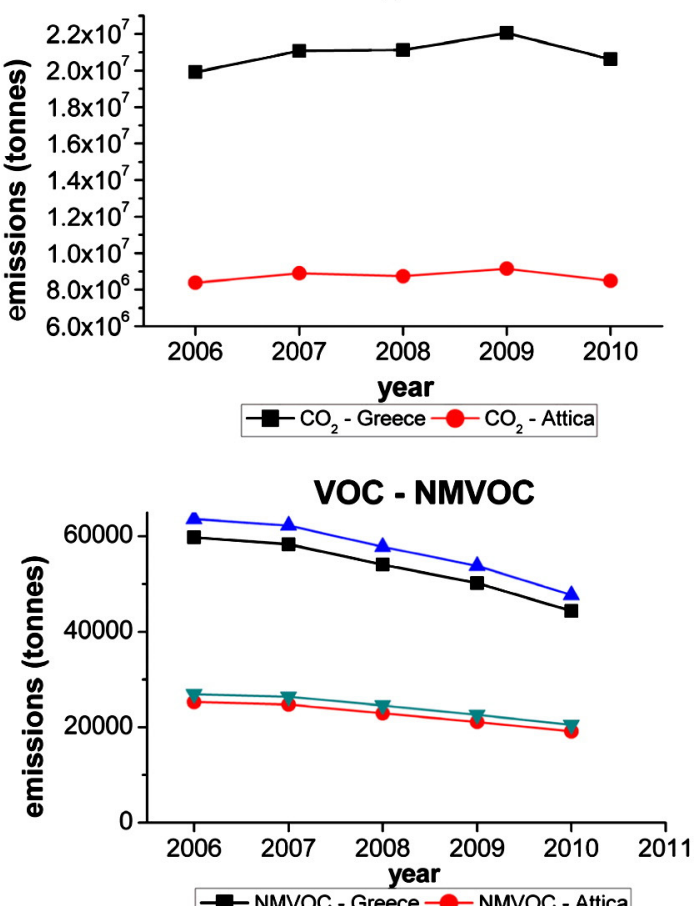

- NMVOC - Greece - NMVOC - Attica - VOC - Greece $\rightarrow$-VOC - Attica

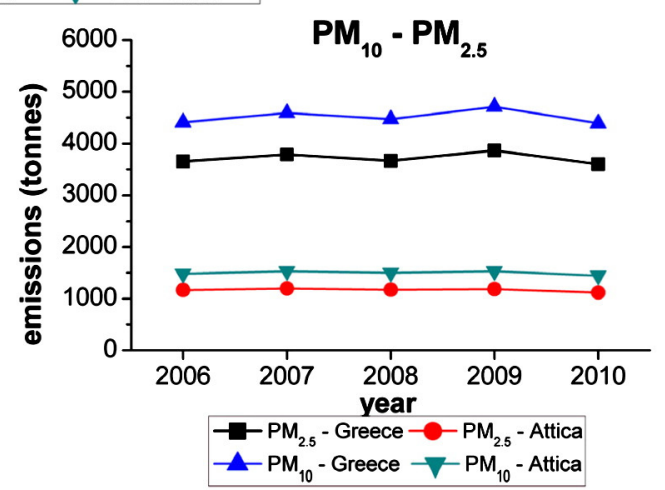

CO
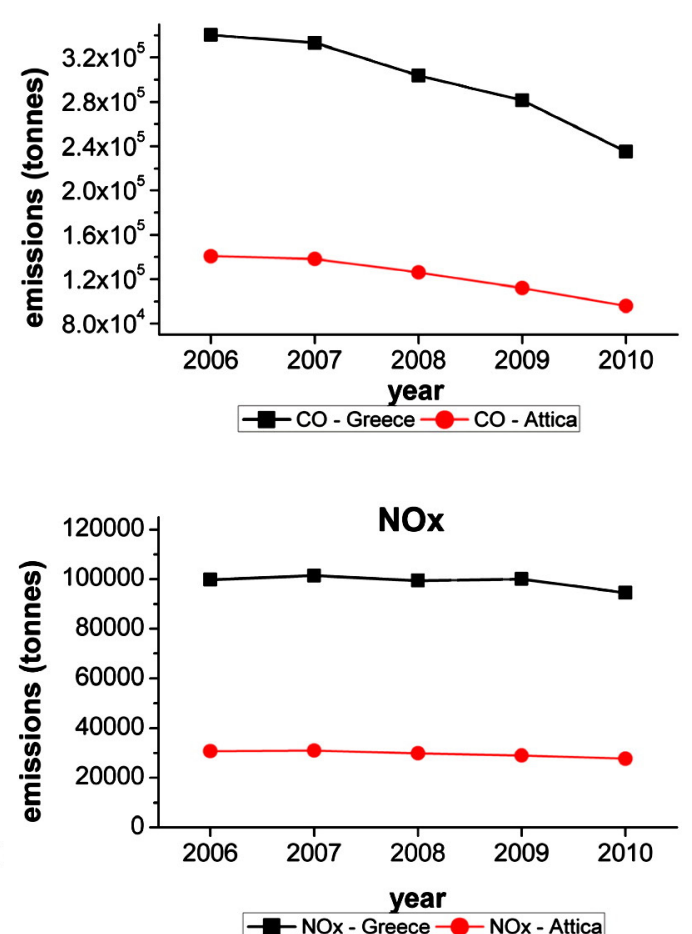

Fig. 6. Annual total emissions for Greece and Attica for the period 2006-2010.

et al., 1998). As shown in Fig. 8, NOx emissions outweigh the VOC emissions for both Greece and Attica. The ratio VOC/NOx is higher for Attica since the diesel vehicle proportion of total fleet is lower for this area

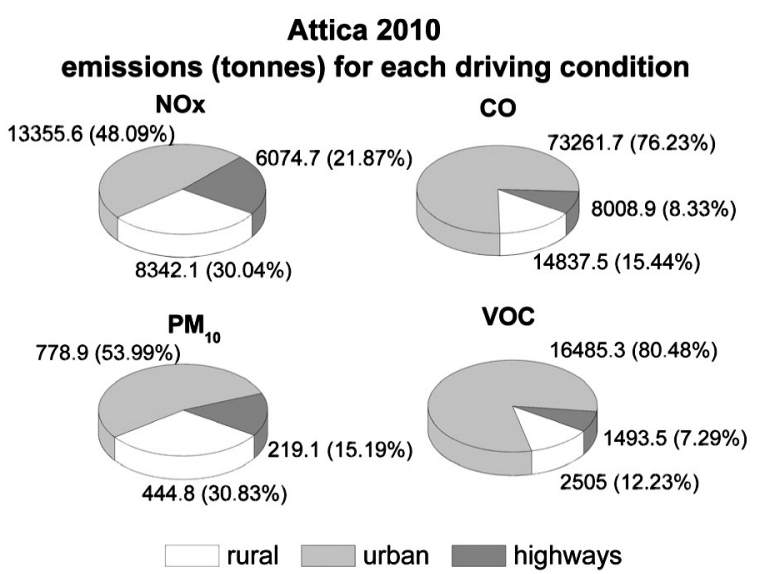

Fig. 7. NOx, CO, $\mathrm{PM}_{10}$ and $\mathrm{VOC}$ emissions share for each of the three driving conditions for Attica for the year 2010 .
(Tables 3 and 4). Generally, a decrease in the VOC/NOx ratio was observed from 2006 to 2010 due to the reduction of VOC emissions (Fig. 4 bottom-right). According to Ziomas et al. (1998), VOC reductions have greater effects on ozone formation within the Greater Athens Area meaning that the reduction of the ratio VOC/NOx will lead to lower $\mathrm{O}_{3}$ values.

Concerning the NMVOC speciation for Attica, alkanes prevailed among other species (8.834 tn for 2010) with aromatic HC coming next (6.415 tn for 2010) and alkenes following (2568 tn for 2010) (Fig. 9 left). According to Atkinson (2000) alkanes neither photolyze nor react with $\mathrm{O}_{3}$. It is their reaction with $\mathrm{OH}$ that leads to the production of $\mathrm{NO}_{2}$. Only cycloalkanes can lead to PM formation $(0.63 \%$ of total NMVOC). 3-Methylpentane, isopentane, 2-methylpentane, butane and pentane are the prevailing alkanes (Fig. 9 right). Aromatic HCs play a dominant role to the formation of particles in urban areas (Atkinson, 2000; Odum et al., 1997) - toluene, m-p-xylene and benzene are between the top 10 NMVOC species (Fig. 9 right). Their impact on $\mathrm{O}_{3}$ production is also very important as their contribution leads to a significant increase in $\mathrm{O}_{3}$ concentrations in Athens (Bossioli et al., 2002). Alkenes and aldehydes, despite their lower contribution to total NMVOC emissions (2568 tn-732 tn respectively), are very reactive and lead to the conversion of $\mathrm{NO}$ to $\mathrm{NO}_{2}$ and consequently to $\mathrm{O}_{3}$ 
Table 7

Emissions in tonnes per vehicle type for the year 2010 for Attica and the percentages of each vehicle category to the total emission value for each pollutant and $\mathrm{CO}_{2}$.

\begin{tabular}{|c|c|c|c|c|c|c|}
\hline Pollutant/vehicle type & PC & LCV & HDV & Buses & Motorcycles & Total \\
\hline \multirow[t]{2}{*}{$\mathrm{CO}$} & $54,332.16$ & $12,866.77$ & 3633.86 & 953.25 & $24,322.06$ & $96,108.09$ \\
\hline & $56.53 \%$ & $13.39 \%$ & $3.78 \%$ & $0.99 \%$ & $25.31 \%$ & $100.00 \%$ \\
\hline \multirow[t]{2}{*}{ NOx } & 5915.48 & 2574.51 & $14,240.23$ & 4257.08 & 785.15 & $27,772.46$ \\
\hline & $21.30 \%$ & $9.27 \%$ & $51.27 \%$ & $15.33 \%$ & $2.83 \%$ & $100.00 \%$ \\
\hline \multirow[t]{2}{*}{ VOC } & $11,909.47$ & 1841.21 & 1147.85 & 245.97 & 5339.27 & $20,483.77$ \\
\hline & $58.14 \%$ & $8.99 \%$ & $5.60 \%$ & $1.20 \%$ & $26.07 \%$ & $100.00 \%$ \\
\hline \multirow[t]{2}{*}{ NMVOC } & $11,253.54$ & 1785.78 & 1045.90 & 179.30 & 4887.01 & $19,151.54$ \\
\hline & $58.76 \%$ & $9.32 \%$ & $5.46 \%$ & $0.94 \%$ & $25.52 \%$ & $100.00 \%$ \\
\hline \multirow[t]{2}{*}{$\mathrm{PM}_{2.5}$} & 306.36 & 140.89 & 493.25 & 92.97 & 88.38 & 1121.86 \\
\hline & $27.31 \%$ & $12.56 \%$ & $43.97 \%$ & $8.29 \%$ & $7.88 \%$ & $100.00 \%$ \\
\hline \multirow[t]{2}{*}{$\mathrm{PM}_{10}$} & 512.15 & 168.60 & 550.11 & 106.59 & 105.41 & 1442.86 \\
\hline & $35.50 \%$ & $11.69 \%$ & $38.13 \%$ & $7.39 \%$ & $7.31 \%$ & $100.00 \%$ \\
\hline \multirow[t]{2}{*}{$\mathrm{CO}_{2}$} & $5,616,634.38$ & $687,888.78$ & $1,401,236.55$ & $455,946.42$ & $329,631.56$ & $8,491,337.68$ \\
\hline & $66.15 \%$ & $8.10 \%$ & $16.50 \%$ & $5.37 \%$ & $3.88 \%$ & $100.00 \%$ \\
\hline
\end{tabular}

formation (Pusede and Cohen, 2012). Especially the presence of ethylene and formaldehyde is very important in urban areas (Jenkin and Clemitshaw, 2000). Their share to NMVOC is 8\% (Fig. 9 right) and $1.63 \%$ respectively (not shown here).

\subsection{Spatial and temporal allocation}

The spatial allocation of $\mathrm{CO}$ emissions on Greece's national highways for 2010 (Fig. 10 right) revealed that peaks were located close to Athens and at motorways that connect the two larger cities (Athens and Thessaloniki). In the case of urban emissions, cells representing high population densities (large cities of Greece) were associated with higher values of $\mathrm{CO}$ (Fig. 10 left). The spatial allocation of total CO, NOx, $\mathrm{PM}_{2.5}$ and VOC emissions in Attica (Fig. 11) showed that high values are concentrated over the urban area of Athens with cells of high NOx and $\mathrm{PM}_{2.5}$ emissions located at the local highways.

Monthly, weekly and hourly traffic flow profiles are shown in Fig. 12 for Attica for the year 2010. Higher traffic flows are found during May, June, July and September while the lowest values are reported in August due to summer vacations (Fig. 12 top left). Concerning weekly profiles (Fig. 12 top right) there is an obvious difference between weekdays and weekends following the working schedule. Higher values are observed on Friday compared to the other weekdays probably because it is the last day of the week. In Fig. 12 bottom, hourly traffic profiles were chosen for Sunday and Friday (being the most populated day) for the winter and summer months. Profiles for both months on Friday are highly correlated with the working hours having a morning peak at 8.00 LST and a second one from 16.00 to 19.00 LST since the working hours vary. The temporal distribution of traffic data is quite different on Sunday when higher values appear at 14.00 LST as well as in the afternoon.

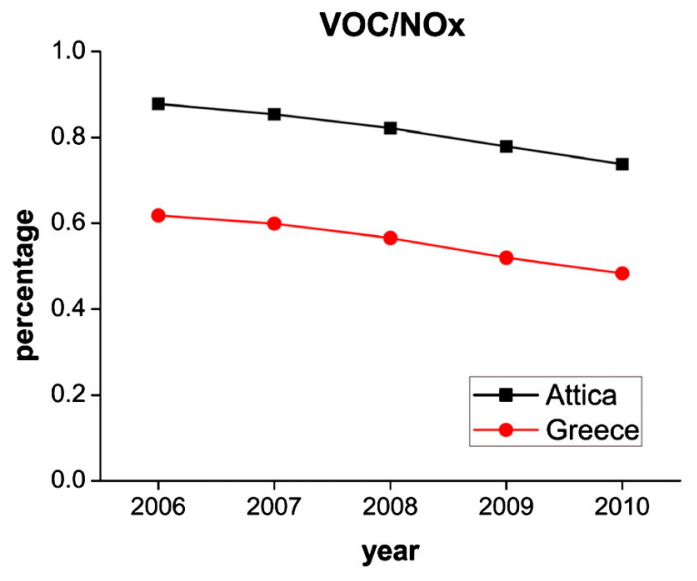

Fig. 8. VOC/NOx ratio for Greece and Attica.
According to Funk et al. (2001) and Mellios et al. (2006), a method to validate road traffic urban emission inventories is to perform a comparison between emission estimates and ambient air quality data by using $\mathrm{CO} / \mathrm{NOx}$ ratio. This emission inventory evaluation method is based on the premise that in urban areas, ambient primary pollutant concentrations are influenced by fresh emissions in the vicinity of the ambient monitor. However, precursor transport, carryover effects, and chemical reactions can also influence ambient concentrations. The influence of these effects on the comparison is minimised but not eliminated by selecting monitoring sites located in areas with high emission rates and by examining data collected when wind speeds and photochemical reaction rates are low. In order to minimise the impact from the above parameters early morning periods should be selected. This is due to the fact that, during the early morning hours, emissions are high while wind speed, atmospheric mixing height, temperature, and chemical reactivity are low (Funk et al., 2001). Parrish et al. (2002) also showed that ambient measurements at carefully selected urban sites accurately reflect the absolute values and temporal trends of the $\mathrm{CO} / \mathrm{NOx}$ ratio on road vehicle emissions.

In this frame, the $\mathrm{CO}$ and NOx hourly emissions were compared with hourly measurements from the urban traffic station Patision, of the air quality monitoring network of the Ministry of Environment, Energy and Climate Change, which overlooks the busy Patision road so it is highly correlated with road emissions in agreement with Kourtidis et al. (1999). The diurnal correlation between the CO and NOx emissions and the measured concentrations were evaluated for the year 2010 covering the morning period 6.00-10.00 LST for winter (February) and summer (June) (Fig. 13). Hourly mean values of Friday for each of the above months were used since during this day the highest traffic flows were attributed. Statistical parameters (bias, correlation coefficient and Root Mean Square Error) were calculated for the monthly and hourly E.I. values and measurements and are presented in Table 8. Results revealed a satisfactory correlation (Table 8) for CO. Both emissions and concentrations had the same morning peak at 9.00 LST in February and at 8.00 LST in June. Differences in values appeared for NOx in February as the concentrations reached the highest value at 7.00 LST and then decreased contrary to the emission morning variation that reached the highest value at 9.00 LST. The correlation between NOx emissions and measurements for both February and June was very poor. The ratios of $\mathrm{CO} / \mathrm{NOx}$ for each month are also presented in Fig. 13. In February the emission inventory ratios appeared greater than the measurement ratio for the period 6.00-8.00 LST (five times greater at 7.00 LST) due to the high CO emissions that were attributed in the morning. There was a good agreement though from 8.00 LST to 10.00 LST. However in June, although there was a good agreement in ratios in the early morning after 9.00 LST the emission inventory ratio was almost half of the measurement ratio. According to Funk et al. (2001), 25\% agreement would be considered acceptable for this type of analysis. 


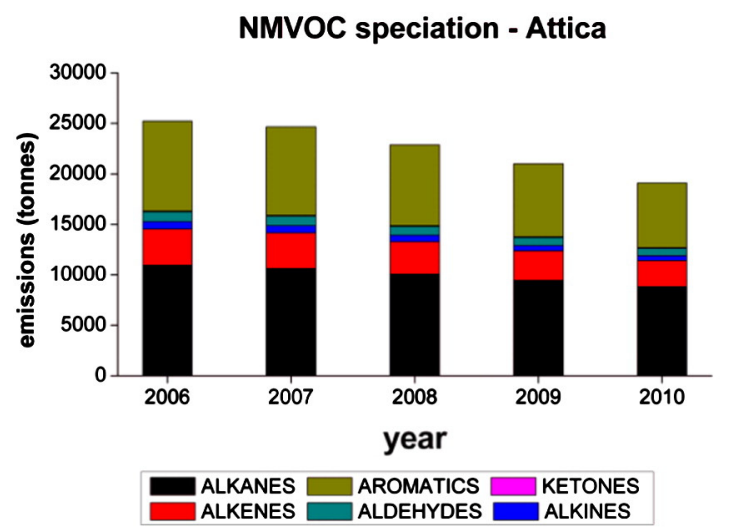

\section{Top10 NMVOC species - Attica 2010 emissions (tonnes, \% of total NMVOC)}

Fig. 9. NMVOC speciation for the total Attica NMVOC emissions (left) and the ten NMVOC species with the highest values (right).

\subsection{Scenario results}

The results from the scenario A-G estimates are presented in Fig. 14 for the pollutants $\mathrm{CO}, \mathrm{NOx}, \mathrm{VOC}, \mathrm{PM}_{2.5}$, and $\mathrm{PM}_{10}$ and the greenhouse gas $\mathrm{CO}_{2}$. The emissions for 2010 are also presented as reference for comparison.

* Scenario A. Regarding sub-scenario 2010_1, lower CO (2330.4 tn2.4\%), VOC (822 tn-4.0\%) and $\mathrm{CO}_{2}$ (216157.2 tn-2.5\%) emissions were estimated compared with the initial 2010 ones. On the contrary NOx, $\mathrm{PM}_{2.5}$ and $\mathrm{PM}_{10}$ values increased -4075.2 th (14.7\%), 12.0 th $(1.1 \%)$ and 10.1 th $(0.7 \%)$ respectively. The influence of replacing 773.551 gasoline PCs with diesel ones (sub-scenario 2010_2) was not much different from subscenario 2010_1 - CO, VOC and $\mathrm{CO}_{2}$ values decreased at about $4.3 \%, 6.7 \%$ and $2.6 \%$ respectively while $\mathrm{NOx}, \mathrm{PM}_{2.5}$ and $\mathrm{PM}_{10}$ values were higher from 2010 at about $23.5 \%, 0.35 \%$ and $0.17 \%$. However, when the ratio of gasoline/diesel PC was 0.7 (sub-scenario 2010_3) the differences in emission profiles between 2010 and 2010_3 were more pronounced. The sharp decrease in CO emissions (24661.4 tn-25.7\%) revealed the impact of gasoline fuel on PC emissions. The impact on VOC values - $28.9 \%$ decrease was similar. On the other hand, NOx emissions increased for subscenario 2010_3 from the year 2010 by $44.7 \%$ as well as particles, $3.5 \%$ for $\mathrm{PM}_{2.5}$ and $5.4 \% \mathrm{PM}_{10}$.

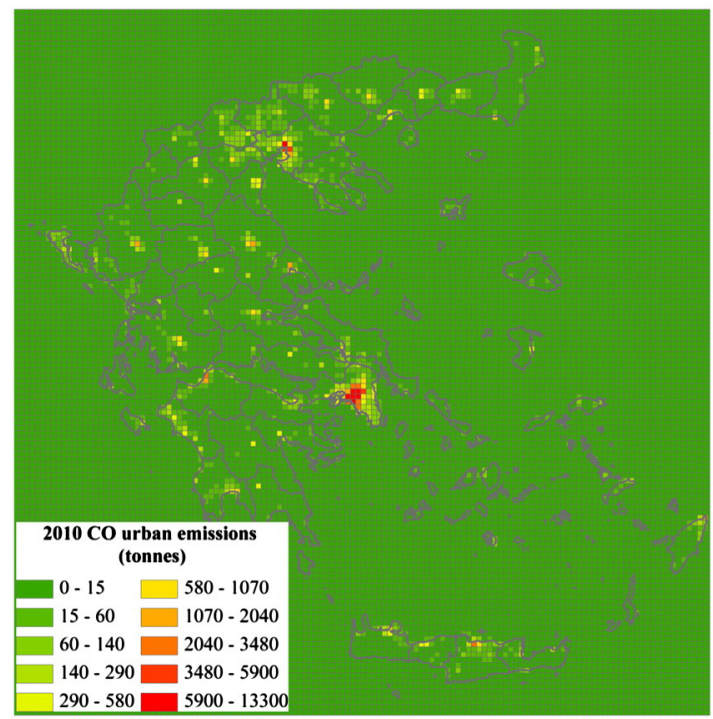

* Scenario B. Changes in HDV fleet had minor impact on CO $(0.76 \%$ difference for $20 \%$ change in fleet), VOC (maximum difference $1.1 \%$ for sub-scenarios 2010_3 and 2010_6) and $\mathrm{CO}_{2}$ emissions (maximum difference 3.3\%). However, NOx emissions were affected by $2.6 \%, 2.1 \%$ and $10.3 \%$ when the change in HDV fleet was $5 \%, 10 \%$ and $20 \%$ respectively. Concerning particles, the maximum percentage difference in $\mathrm{PM}_{2.5}$ emissions was $8.8 \%$ while in $\mathrm{PM}_{10}$ it was $7.6 \%$.

* Scenario C. Generally, emissions increased when rural and highway driving reduced in favour of urban driving. The increase in the share of annual mileage driven in urban conditions for PCs and motorcycles led to $\mathrm{CO}$ and $\mathrm{CO}_{2}$ increase from $0.73 \%$ to $1.9 \%$ at sub-scenario 2010_1 to 8.6\% and 8.7\% at sub-scenario 2010_3 respectively while NOx and particles slightly increased at subscenario 2010_3 (1\% NOx, 2.6\% $\mathrm{PM}_{2.5}$ and 3.74\% $\mathrm{PM}_{10}$ ). According to Vanhulsel et al. (2014) the effect of shift of vehicle kilometres between rural and urban negatively affected emissions when urban driving prevailed due to the different velocities that the kilometres are driven.

* Scenario D. Generally, the increase in mean velocity values for each driving condition affected the emissions positively, as expected, since engines consume less fuel at higher velocities. CO emissions were lower by $38.39 \%$ at sub-scenario 2010_3 when the greatest velocity values were used while the reduction in VOC, $\mathrm{PM}_{10}$ and $\mathrm{CO}_{2}$ emissions was $29.28 \%, 20.54 \%$ and $18.55 \%$ respectively.

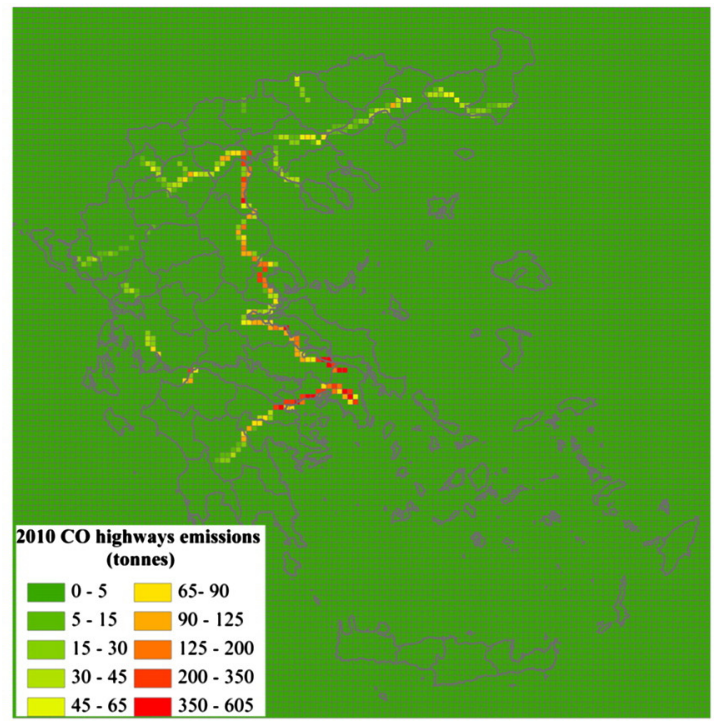

Fig. 10. CO national urban (left) and highway (right) emissions in gridded form for the year 2010. 

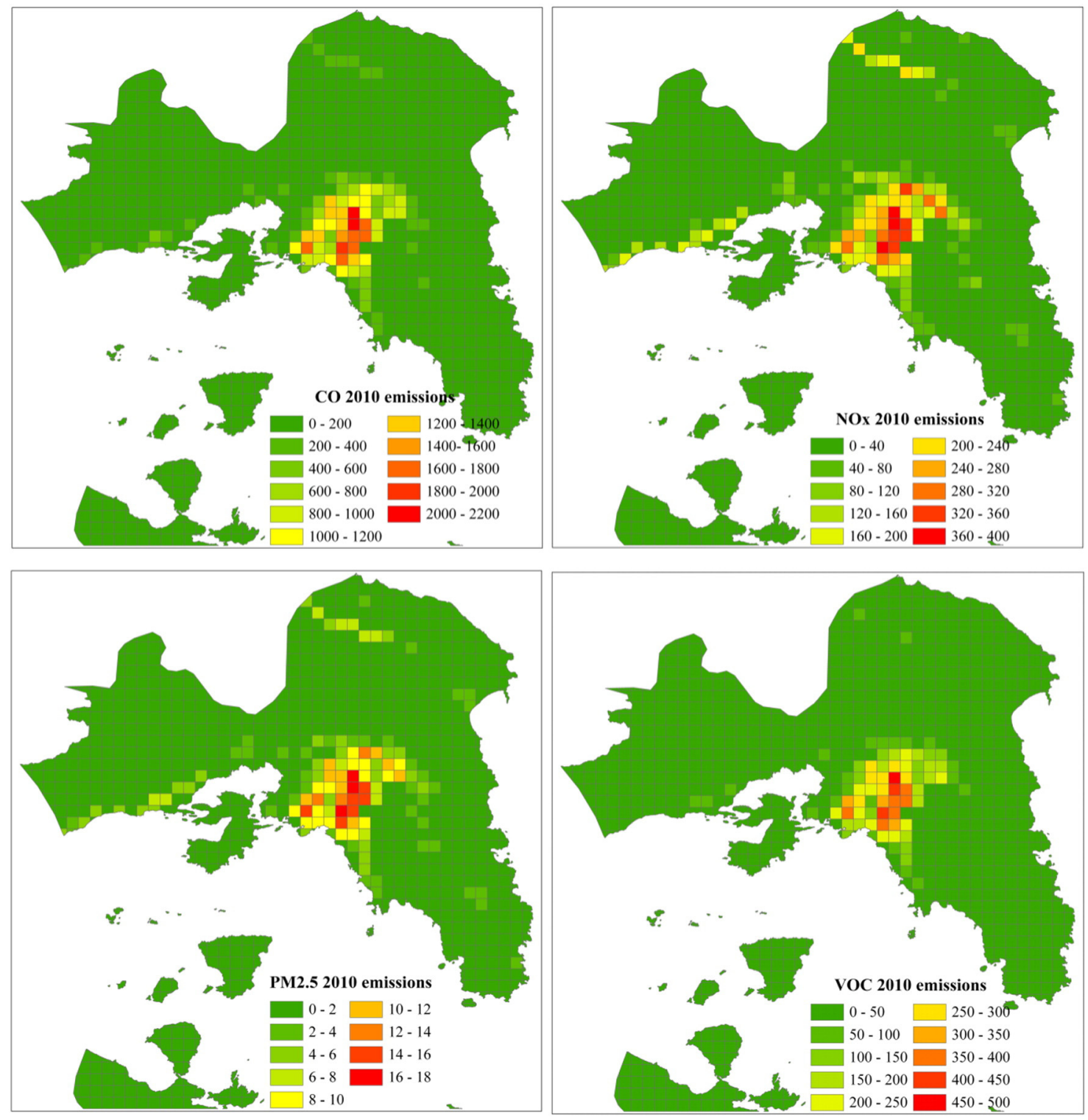

Fig. 11. Gridded CO, NOx, $\mathrm{PM}_{2.5}$ and VOC emissions for Attica for the year 2010.

Results from sub-scenario 2010_4 11.8\% (11356.2 tn) decrease of CO emissions, $14.2 \%$ (2169.0 tn) decrease of NOx, 18.5\% (1156701.0 tn) decrease of $\mathrm{CO}_{2}$ and $20.5 \%$ (125.3 tn) decrease of $\mathrm{PM}_{10}$.

* Scenario E. The effect on emissions from the decrease of the trip length by $6.4 \mathrm{~km}$ amounted to an increase of $14.6 \%$ for $\mathrm{CO}$, $13.3 \%$ for $\mathrm{VOC}, 3.0 \%$ for $\mathrm{CO}_{2}, 1.3 \%$ for $\mathrm{NOx}, 0.7 \%$ for $\mathrm{PM}_{2.5}$ and $0.6 \%$ for $\mathrm{PM}_{10}$. On the contrary, the increase of trip length led to respective percentage decreases on emissions.

* Scenario F. The average temperature is required by COPERT as input for evaporation and cold-start calculations. As shown in Fig. 14 the temperature changes slightly influenced NOx, particles and $\mathrm{CO}_{2}$ emissions indicating that they are not related to the above processes. However, a $20 \%$ decrease in temperaure resulted in an $11.6 \%$ increase of CO while the $20 \%$ increase in temperature affected VOC emissions that increased by $21.7 \%$.

* Scenario G. The replacement of 20\% Pre-Euro PCs by Euro 5 PCs led to the reduction of CO, VOC and NOx 2010 emissions by 2650 tn (2.76\%), 577 tn (2.81\%) and 323 tn (1.16\%), respectively. However, particles and $\mathrm{CO}_{2}$ slightly increased. In sub-scenario 2010_2 the decrease in CO, VOC and NOx, was 5.69\%, 5.91\% and $2.20 \%$, respectively compared with 2010 while $\mathrm{CO}_{2}$ and particle emissions increased (3.84\% for $\mathrm{CO}_{2}, 1.01 \%$ for $\mathrm{PM}_{2.5}$ and $1.54 \%$ for $\mathrm{PM}_{10}$ ). The consideration that $20 \%$ of Pre-Euro, Euro 1, 2 and 3 PCs were withdrawn and vehicles having newer engine technology (Euro5) came into the market, had greater positive impacts on CO, VOC, NOx and particle emissions (sub-scenario 2010_3). Comparing results with 2010 emissions, CO decreased by $10.15 \%$ ( $9787 \mathrm{tn}$ ), NOx by $3.48 \%$ (966 tn), VOC by $8.25 \%$ (1690 tn) and $\mathrm{PM}_{10} 0.91 \%$ (13 tn) while only $\mathrm{CO}_{2}$ increased by $1.28 \%(108,592 \mathrm{tn})$. The changes in $\mathrm{CO}_{2}$ emissions are related to fuel consumption. Generally, it was considered that more kilometres are travelled by newer vehicles for all the runs with COPERT (the period 2006-2010 and the scenarios). While changing the engine technology, the kilometres driven by each vehicle category remained stable. As a consequence, in sub-scenarios Euro 5 PCs were attributed to more annual mileage causing the increase in $\mathrm{CO}_{2}$ emissions. Concerning particles, engine technology positively affected their emissions only in sub-scenario 2010_3 due to the reduction of Euro 3 PCs.

\subsection{Comparison with other emission inventories}

Apart from collecting the most reliable and updated data for the development of a national and regional emission inventory it is very 


\section{Monthly, daily and hourly mean traffic flows Attica 2010}

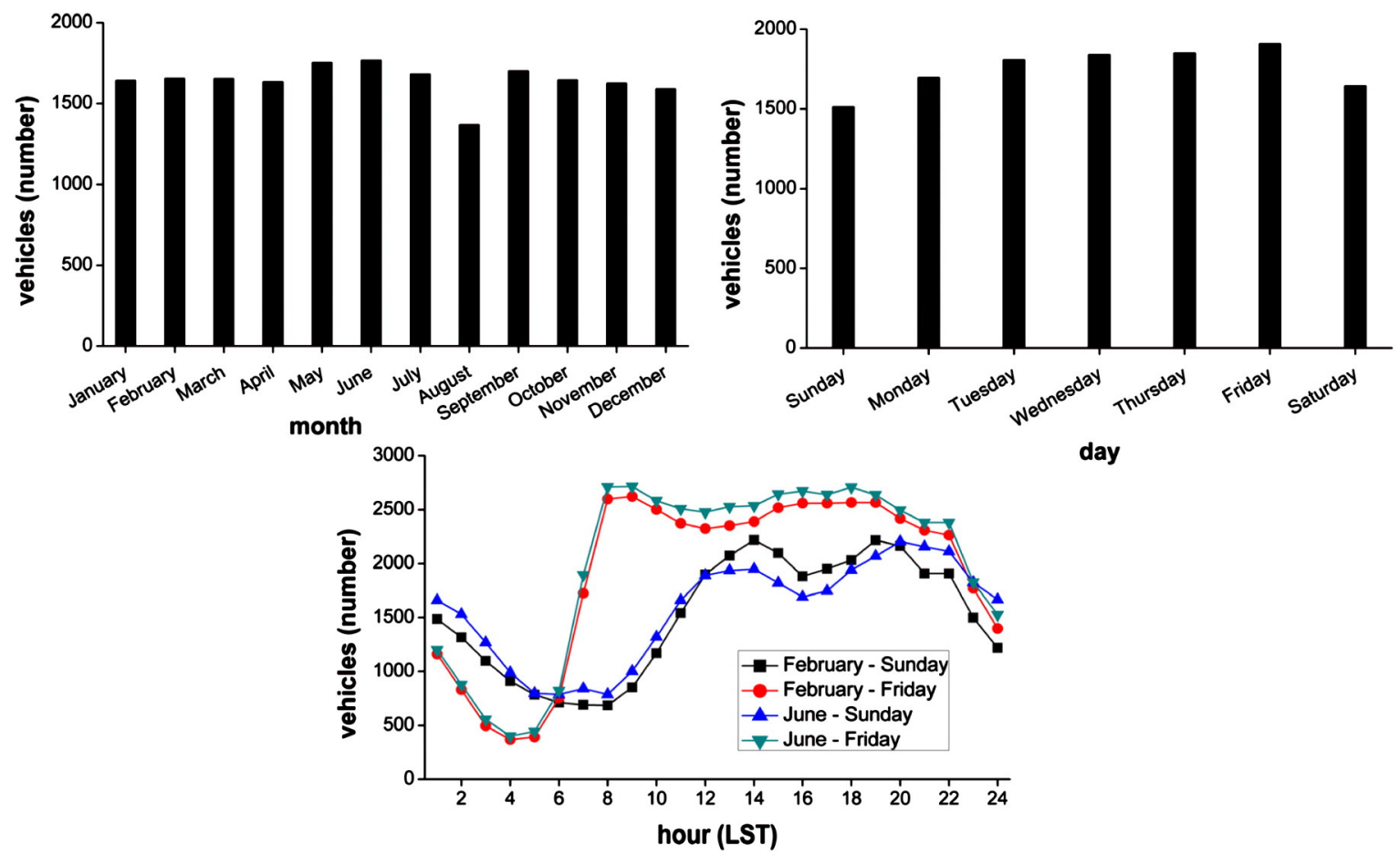

Fig. 12. Traffic flow data for the Attica region - mean monthly, daily and hourly values for the year 2010.

important to compare the results with other emission inventories. In this frame road transport emissions for Greece and Attica from different studies are conveniently presented in Table 9. These data include national emissions for the road transport sector from the online WebDab - EMEP database (http://www.ceip.at/webdab-emissiondatabase/emissions-as-used-in-emep-models) covering the same period with this study (2006-2010) and road emissions calculated by other researchers. Comparing national emissions from this study with the EMEP values one may observe that EMEP values surpass the values of this study for the whole examined period for $\mathrm{CO}$ and $\mathrm{NOx}$, while there is a good agreement in NMVOC emissions. However, when the ratios of $\mathrm{CO} / \mathrm{NOx}$ are calculated for both datasets it is found that the results are in

\section{February - Friday}
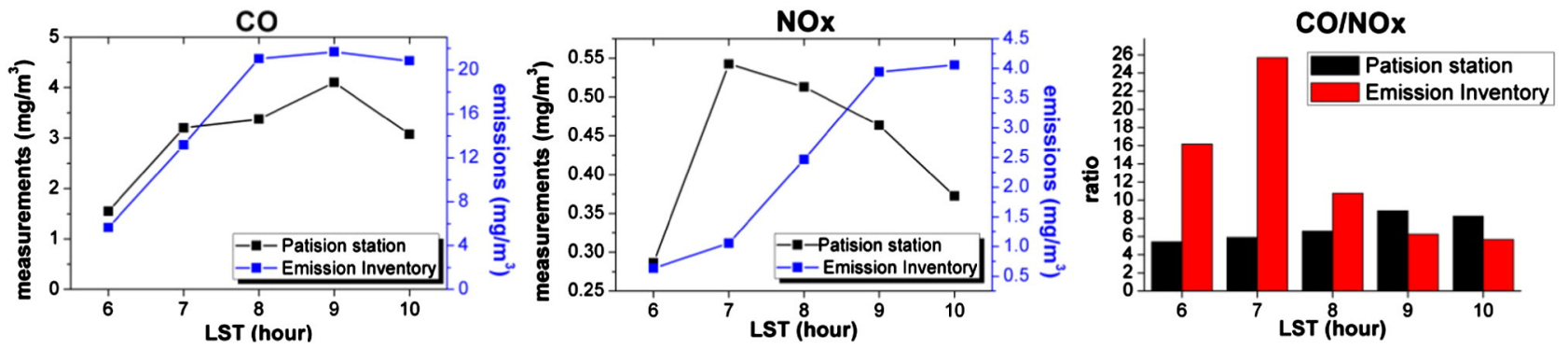

\section{June - Friday}
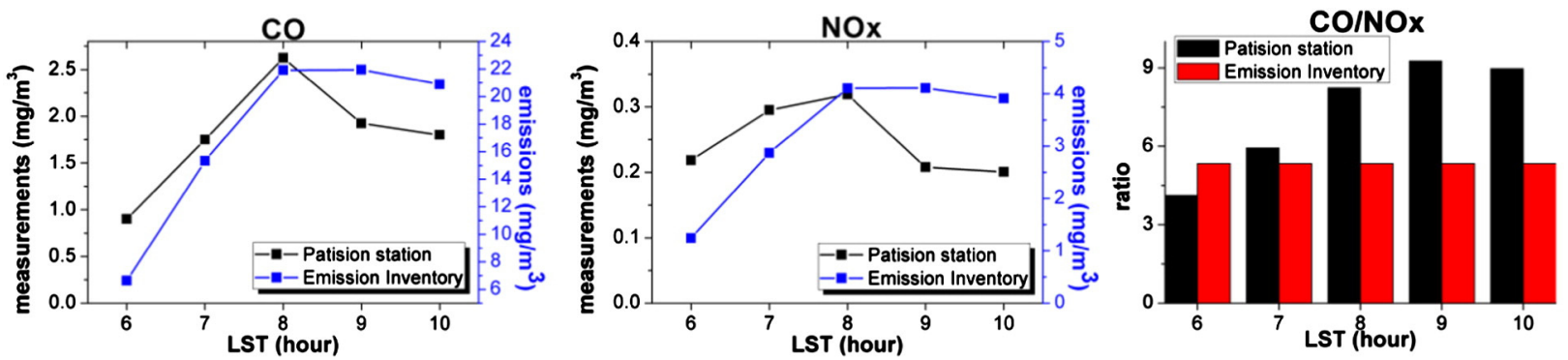

Fig. 13. Hourly mean CO values from the emission inventory (E.I.) and the ambient concentrations (Patision station) for February and June (values for Friday only). 
Table 8

Statistical parameters from the comparison of Attica emissions with measurements for a typical weekday (Friday).

\begin{tabular}{lcccll}
\hline & CO & & & \multicolumn{2}{l}{ NOx } \\
\cline { 2 - 3 } \cline { 6 - 6 } & February & June & & February & June \\
\hline $\mathrm{R}^{2}$ & 0.765 & 0.758 & & 0.009 & 0.018 \\
$\mathrm{r}$ & 0.875 & 0.871 & & 0.095 & 0.134 \\
Bias & 13.409 & 15.543 & & 1.995 & 2.999 \\
\hline
\end{tabular}

excellent agreement (3.37 for this study, 3.43 for the EMEP database in 2006, 2.65 for this study and 2.75 for the EMEP database in 2010). Large discrepancies exist between Markakis et al. (2010) results and the EMEP database for national emissions in 2003 (Table 9). National emissions calculated by Progiou and Ziomas (2012) are higher by 100.845 ktn for CO, $33.263 \mathrm{ktn}$ for NOx and 7.251 ktn for NMVOC from this study. Concerning the emissions for the Attica region they seem to be comparable to this study for CO (except for Markakis et al., 2010 but emissions are calculated for 2003) while for NOx and NMVOC the difference is $22 \%$ and 51\% respectively between Aleksandropoulou et al. (2011) and this study.

\section{Concluding remarks}

Urban areas continue to face serious air quality problems because of the often high pollutant concentrations which exceed the limits set by the EU. This poses a serious threat to human health and efforts are continuously being made to understand the sources and mechanisms in order to manage air quality effectively. Since road traffic is responsible for the majority of air pollutant emissions, a comprehensive and flexible emission inventory for the road transport sector was created for Greece and Attica, where the Greater Athens Area is located, for the period 2006-2010 according to the EMEP/CORINAIR methodology. The results of this study indicated that:

- The decrease in gasoline consumption in 2008 and 2010 and the subsequent reduction of annual mileage driven combined with the import of new engine anti-pollution technologies affected CO, VOC and NMVOC emissions, while $\mathrm{CO}_{2}$ was mostly related to fuel consumption.

- Comparing Greece and Attica, the emission results revealed that about $40 \%$ of national $\mathrm{CO}_{2}, \mathrm{CO}$, VOC and NMVOC and 30\% of NOx and particles are emitted in Attica. The importance of the urban emissions is shown by the driving condition distribution in Attica. Urban emissions prevailed among emissions in rural roads and highways for all pollutants, although the latter increased their share on PM and NOx.

- Passenger cars contributed mostly to the total CO, VOC, NMVOC and $\mathrm{CO}_{2}$ emissions for the Attica region while heavy duty vehicles dominated the $\mathrm{NOx}, \mathrm{PM}_{2.5}$ and $\mathrm{PM}_{10}$ emissions. Motorcycles also played a significant role to CO, VOC and NMVOC emissions since they are more economic and efficient and consequently very popular to use in urban traffic conditions.

- Concerning the NMVOC speciation for Attica, species leading to $\mathrm{NO}_{2}$ and consequently $\mathrm{O}_{3}$ formation prevailed, while those acting as PM precursors were less important.

- The spatial allocation of CO emissions on national highways in 2010 revealed that peaks appeared at highways close to the Athens basin and at motorways that connect the two larger cities (Athens and Thessaloniki). The emission pattern of total CO, NOx, $\mathrm{PM}_{2.5}$ and VOC for Attica for 2010 showed that higher values were concentrated over the urban area of Athens and at the local motorways.

- Temporal coefficients were developed for Grid 2 from hourly traffic counts covering the main road network of the GAA at both directions. As a consequence yearly, monthly, daily and hourly emission profiles

\section{Attica emissions - scenarios}
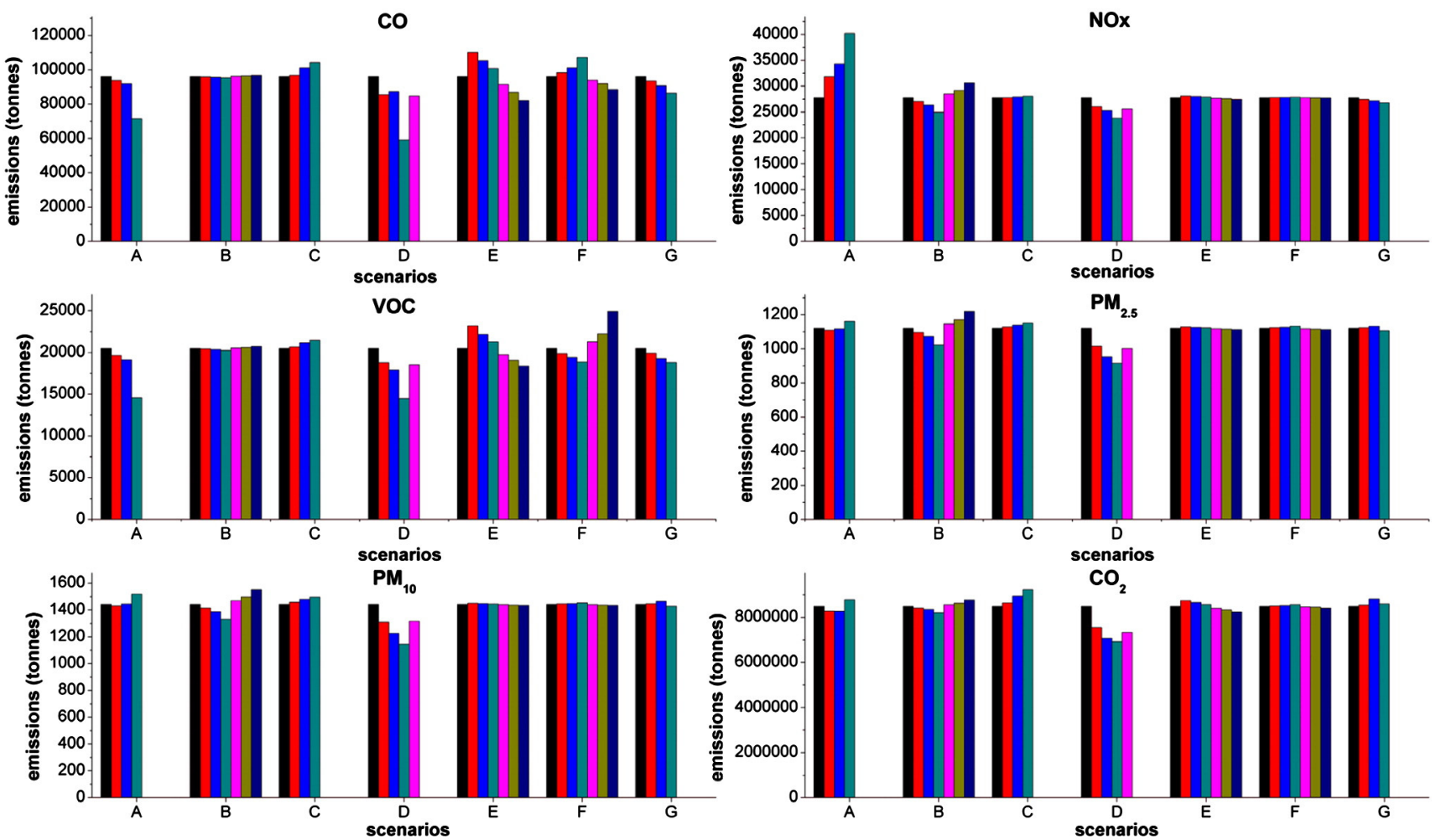

$2010 \square 2010$ 2010_2

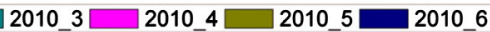

Fig. 14. Pollutant emission changes from the development of the scenarios for Attica. 
were created for the period 2006-2010 highlighting the special characteristics of the GAA traffic.

- The temporal allocation of pollutant emissions exhibited higher values for CO and NOx during May and June while the lowest values were found in August. Concerning weekly traffic flow profiles there was an obvious difference between weekdays and weekends following the weekly working schedule.

- The validation of hourly CO and NOx emissions with ambient measured concentrations from an urban traffic station showed satisfactory correlation for $\mathrm{CO}$ since it is a primary pollutant. Concerning the ratios $\mathrm{CO} / \mathrm{NOx}$ from the emission inventory and the measurements, there was a good agreement from 8.00 LST to 10.00 LST in the cold period. However in June, although there was a good agreement in ratios in the early morning after 9.00 LST the emission inventory ratio was almost half of the measurement ratio. This fact highlights the importance of photochemical activity and chemical reactions that lead to the production of secondary pollutants.

- The fleet composition, the increase of urban average speed and the fleet renewal are among the most effective measures towards the emission reduction strategies.

- In order to have a significant decrease in CO and VOC emissions in Athens, the diesel penetrations among PCs must be of the order of $70 \%$. In such a case however, $\mathrm{NOx}, \mathrm{PM}_{10}$ and $\mathrm{PM}_{2.5}$ and particle emissions will increase by $44.7 \%, 3.5 \%$ and $5.4 \%$ respectively, indicating that dieselisation has different impacts on pollutant emissions which should not be neglected in order to make proper policy decisions.

- The shift to new engine technologies affected emissions positively so the withdrawal of older cars (e.g. with PRE ECE technology) and changes in the taxation system should be promoted by policy makers.

- The increase in mean velocity values for each driving condition positively affected the emissions as expected since engines consume less fuel at higher velocities.

- The CO and VOC emissions are more sensitive than $\mathrm{PM}_{2.5}, \mathrm{PM}_{10}$ and $\mathrm{CO}_{2}$ to variability in parameters such as the trip length, the temperature and the velocity attributed to different driving conditions. Moreover, CO, VOC and NOx are mostly influenced by the fleet composition and the type of fuel used by each vehicle category while the engine technology affected all pollutants and $\mathrm{CO}_{2}$.

Further work to complete the new emission inventory at national level and for Attica will shed light on the contribution of all sources to the pollutant levels. Moreover, modelling of the pollutants' dispersion and chemical transformations will be possible, leading to the assessment of different mitigation strategies on the local and regional air qualities.

\section{Acknowledgements}

This research has been co-financed by the European Union (European Social Fund - ESF) (MIS: 346942) and Greek national funds through the Operational Program "Education and Lifelong Learning" of the National Strategic Reference Framework (NSRF) - Research Funding Program: Heracleitus II. Investing in knowledge society through the European Social Fund. The authors would like to thank the Hellenic Institute of Transport (H.I.T.) and the Attica Traffic Management Centre for providing the necessary traffic counts as well as the Hellenic National Meteorological Service for providing the temperature profiles.

\section{Appendix A. Temporal profiles for SNAP sector 7 (Road transport)}

The temporal profiles available for the year 2010 for the GAA (located in Attica) are presented in the following Tables A.1-A.3. For the development of these temporal coefficients hourly traffic counts were provided by the Attica Traffic Management Centre for the period 2006 - 2010 covering the main road network of the GAA at both directions. As a consequence the yearly, monthly, daily and hourly profiles were created highlighting the special characteristics of the area's traffic. 
Table A.1

Monthly profiles.

\begin{tabular}{|c|c|c|c|c|c|c|c|c|c|c|c|c|}
\hline Month $^{*}$ & 1 & 2 & 3 & 4 & 5 & 6 & 7 & 8 & 9 & 10 & 11 & 12 \\
\hline monthly factor & 0.083305 & 0.083928 & 0.083845 & 0.082865 & 0.088883 & 0.089645 & 0.085298 & 0.069467 & 0.0863 & 0.083411 & 0.082391 & 0.080661 \\
\hline
\end{tabular}

* 1 is for January, 2 is for February, etc.

Table A.2

Weekly profiles.

\begin{tabular}{|c|c|c|c|c|c|c|c|c|c|c|c|}
\hline Month & Day* & daily factor & Month & Day & daily factor & Month & Day & daily factor & Month & Day & daily factor \\
\hline 1 & 1 & 0.120722 & 4 & 1 & 0.122322 & 7 & 1 & 0.114884 & 10 & 1 & 0.12588 \\
\hline 1 & 2 & 0.149096 & 4 & 2 & 0.137453 & 7 & 2 & 0.15072 & 10 & 2 & 0.145334 \\
\hline 1 & 3 & 0.150961 & 4 & 3 & 0.15101 & 7 & 3 & 0.148253 & 10 & 3 & 0.148606 \\
\hline 1 & 4 & 0.142115 & 4 & 4 & 0.15518 & 7 & 4 & 0.151638 & 10 & 4 & 0.1505 \\
\hline 1 & 5 & 0.152316 & 4 & 5 & 0.156609 & 7 & 5 & 0.156424 & 10 & 5 & 0.139055 \\
\hline 1 & 6 & 0.150065 & 4 & 6 & 0.150697 & 7 & 6 & 0.155034 & 10 & 6 & 0.154805 \\
\hline 1 & 7 & 0.134725 & 4 & 7 & 0.126729 & 7 & 7 & 0.123046 & 10 & 7 & 0.135821 \\
\hline 2 & 1 & 0.123364 & 5 & 1 & 0.123541 & 8 & 1 & 0.113072 & 11 & 1 & 0.124443 \\
\hline 2 & 2 & 0.138458 & 5 & 2 & 0.143147 & 8 & 2 & 0.154391 & 11 & 2 & 0.145455 \\
\hline 2 & 3 & 0.14741 & 5 & 3 & 0.147833 & 8 & 3 & 0.156807 & 11 & 3 & 0.146566 \\
\hline 2 & 4 & 0.150088 & 5 & 4 & 0.148072 & 8 & 4 & 0.152032 & 11 & 4 & 0.147138 \\
\hline 2 & 5 & 0.150973 & 5 & 5 & 0.153409 & 8 & 5 & 0.151419 & 11 & 5 & 0.151091 \\
\hline 2 & 6 & 0.155675 & 5 & 6 & 0.155469 & 8 & 6 & 0.155608 & 11 & 6 & 0.151467 \\
\hline 2 & 7 & 0.134033 & 5 & 7 & 0.128529 & 8 & 7 & 0.116672 & 11 & 7 & 0.13384 \\
\hline 3 & 1 & 0.12523 & 6 & 1 & 0.11987 & 9 & 1 & 0.123097 & 12 & 1 & 0.126283 \\
\hline 3 & 2 & 0.147417 & 6 & 2 & 0.148051 & 9 & 2 & 0.144286 & 12 & 2 & 0.143944 \\
\hline 3 & 3 & 0.148505 & 6 & 3 & 0.146876 & 9 & 3 & 0.145228 & 12 & 3 & 0.147975 \\
\hline 3 & 4 & 0.148304 & 6 & 4 & 0.14915 & 9 & 4 & 0.15075 & 12 & 4 & 0.149993 \\
\hline 3 & 5 & 0.138989 & 6 & 5 & 0.153781 & 9 & 5 & 0.151569 & 12 & 5 & 0.152361 \\
\hline 3 & 6 & 0.154019 & 6 & 6 & 0.153332 & 9 & 6 & 0.15358 & 12 & 6 & 0.148899 \\
\hline 3 & 7 & 0.137535 & 6 & 7 & 0.128939 & 9 & 7 & 0.13149 & 12 & 7 & 0.130545 \\
\hline
\end{tabular}

* 1 is for Sunday, 2 is for Monday, etc.

\section{References}

ACEA (European Automobile Manufacturers Association). The automobile industry, pocket guide 2013; 2013

Aleksandropoulou V, Lazaridis M. Spatial distribution of gaseous and particulate matter emissions in Greece. Water Air Soil Pollut 2004;153:15-34. http://dx.doi.org/10. 1023/B:WATE.0000019923.58620.58.

Aleksandropoulou V, Torseth K, Lazaridis M. Atmospheric emission inventory for natural and anthropogenic sources and spatial emission mapping for the Greater Athens Area. Water Air Soil Pollut 2011;219:507-26. http://dx.doi.org/10.1007/s11270010-0724-2.

ANFAC(Asiciacion Espanola de Fabricantes de Automoviles y Camiones). European Motor Vehicle Parc 2010; April 2012

Atkinson R. Atmospheric chemistry of VOCs and NOx. Atmos Environ 2000;34:2063-101. http://dx.doi.org/10.1016/S1352-2310(99)00460-4.

Ban-Weiss GA, McLaughlin JP, Harley RA, Lunden MM, Kirchstetter TW, Kean RA, et al. Long-term changes in emissions of nitrogen oxides and particulate matter from onroad gasoline and diesel vehicles. Atmos Environ 2008;42:220-32. http://dx.doi. org/10.1016/j.atmosenv.2007.09.049.

Bossioli E, Tombrou M, Pilinis C. Adapting the speciation of the VOCs emission inventory in the Greater Athens Area. Water Air Soil Pollut 2002;2:141-53. http://dx.doi.org/10. 1023/A:1019999528315. [doi: http://dx.doi.org/10.1023/A:1021302427057].

Bossioli E, Tombrou M, Dandou A, Soulakelis N. Simulation of the effects of critical factors on ozone formation and accumulation in the Greater Athens Area. J Geophys Res 2007;112:D02309. http://dx.doi.org/10.1029/2006JD007185.

Coelho M, Fontes T, Bandeira JM, Pereira SR, Tchepel O, Dias D, et al. Assessment of potential improvements on regional air quality modelling related with implementation of a detailed methodology for traffic emission estimation. Sci Total Environ 2014; 470-471:127-37. http://dx.doi.org/10.1016/j.scitotenv.2013.09.042.

Colvile RN, Hutchinson EJ, Mindell JS, Warren RF. The transport sector as a source of air pollution. Atmos Environ 2001;35:1537-65. http://dx.doi.org/10.1016/S13522310(00)00551-3.

Economopoulos A. Management of space heating emissions for effective abatement of urban smoke and $\mathrm{SO}_{2}$ pollution. Atmos Environ 1997;31:1327-37. http://dx.doi. org/10.1016/S1352-2310(96)00297-X.

EEA (European Environmental Agency). The contribution of transport to air quality. TERM 2012: transport indicators tracking progress towards environmental targets in Europe. EEA technical report no 10/2012; 2012.

EEA (European Environmental Agency). Air quality in Europe - 2013 report. EEA report no 9/2013; 2013a.

EEA (European Environmental Agency). European Union emission inventory report 1990-2011 under the UNECE Convention on Long-range Transboundary Air Pollution (LRTAP). EEA technical report no 10/2013; 2013b.
EEA (European Environmental Agency). EMEP/EEA air pollutant emission inventory guidebook 2013. EEA technical report no 12/2013; 2013c.

EEA(European Environment Agency). Annual European Union greenhouse gas inventory 1990-2011 and inventory report 2013, EEA technical report no 8/2013 2013d.

Eurostat. European Forum for GeoStatistics. GEOSTAT 1A - representing census data in a European population grid. Final report 2012; 2012.

Fameli KM, Assimakopoulos VD, Kotroni V, Retalis A. Effects of the land use change characteristics on the air pollution patterns above the Greater Athens Area (GAA) after 2004. Glob. NEST J. 2013;15(2):169-77.

Funk TH, Chinkin LR, Roberts PT, Saeger M, Mulligan S, Paramo Figueroa VH, et al. Compilation and evaluation of a Paso del Norte emission inventory. Sci Total Environ 2001;276:135-51. http://dx.doi.org/10.1016/S0048-9697(01)00776-8.

Giannouli M, Kalognomou EA, Mellios G, Moussiopoulos N, Samaras Z, Fiala J. Impact of European emission control strategies on urban and local air quality. Atmos Environ 2011;45(27):4753-62. http://dx.doi.org/10.1016/j.atmosenv.2010.03.016

Gkatzoflias D, Kouridis C, Ntziachristos L, Samaras Z. COPERT 4 computer programme to calculate emissions from road transport. User manual (version 9.0); February 2012.

Gonzalez RM, Marrero GA. The effect of dieselisation in passenger cars emissions for Spanish regions: 1998-2006. Energ Policy 2012;51:213-21. http://dx.doi.org/10. 1016/j.enpol.2012.03.033.

Grivas G, Chaloulakou A, Kassomenos P. An overview of the $\mathrm{PM}_{10}$ pollution problem, in the Metropolitan Area of Athens, Greece. Assessment of controlling factors and potential impact of long range transport. Sci Total Environ 2008;389:165-77. http:// dx.doi.org/10.1016/j.scitotenv.2007.08.048

Hanna SR, Lu Z, Frey HC, Wheeler N, Vukovich J, Arunachala S, et al. Uncertainties in predicted ozone concentrations due to input uncertainties for the UAM-V photochemical grid model applied to the July 19950TAG domain. Atmos Environ 2001;35:891-903. http://dx.doi.org/10.1016/S1352-2310(00)00367-8.

Hatzianastassiou N, Katsoulis BD, Antakis. Extreme nitrogen and ozone concentrations in Athens atmosphere in relation to meteorological conditions. Environ Monit Assess 2007;128:447-64. http://dx.doi.org/10.1007/s10661-006-9338-y.

Hoek G, Meliefste K, Cyrys J, Lewne M, Bellander T, Brauer M, et al. Spatial variability of fine particle concentrations in three European areas. Atmos Environ 2002;36: 4077-88. http://dx.doi.org/10.1016/S1352-2310(02)00297-2.

ICCT (International Council on Clean Transportation). Campestrini M and Mock Peter. European Vehicle Market Statistics. Pocketbook 2011 Edition; 2011.

IPCC. In: Eggleston HS, Buendia L, Miwa K, Ngara T, Tanabe K, editors. IPCC guidelines for National Greenhouse Gas Inventories, prepared by the National Greenhouse Gas Inventories Programme. Japan: IGES; 2006.

Jenkin ME, Clemitshaw KC. Ozone and other secondary photochemical pollutants: chemical processes governing their formation in the planetary boundary layer. Atmos Environ 2000;34:2499-527. http://dx.doi.org/10.1016/S1352-2310(99)00478-1. 
Table A.3

Hourly profiles (provided only for January and June).

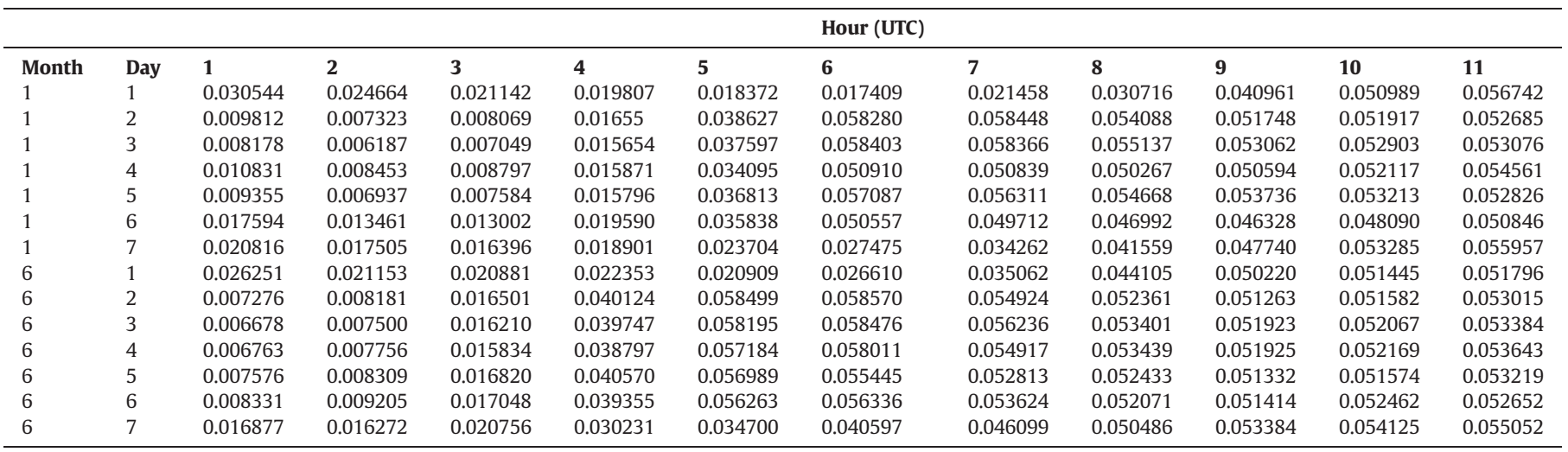

Kalabokas PD, Papayannis AD, Ziomas I. A study on the atmospheric concentrations of primary and secondary air pollutants in the Athens basin performed by DOAS and DIAL measuring techniques. Sci Total Environ 2012;414:556-63. http://dx.doi.org/10. 1016/j.scitotenv.2011.11.024

Kassomenos P, Karakitsios S, Papaloukas C. Estimations of daily traffic emissions in a South-European urban agglomeration during a workday. Evaluation of several "what if" scenarios. Sci Total Environ 2006;370:480-90. http://dx.doi.org/10.1016/j. scitotenv.2006.08.018.

Kassomenos P, Vardoulakis S, Chaloulakou A, Grivas G, Borge R, Lumbreras J. Level, sources and seasonality of coarse particles (PM10-PM2.5) in three European capitals - implications for particulate pollution control. Atmos Environ 2012;54:337-47. http://dx.doi.org/10.1016/j.atmosenv.2012.02.051.

Katsis P, Ntziachristos L, Mellios G. Description of new elements in COPERT 4 v10.0. EMISIA SA 2012. Report no: 12.RE 012.V1; 2012.

Kourtidis KA, Ziomas IC, Rappenglueck B, Proyou A, Balis D. Evaporative traffic hydrocarbon emissions, traffic $\mathrm{CO}$ and speciated $\mathrm{HC}$ traffic emissions from the city of Athens. Atmos Environ 1999;33:3831-42. http://dx.doi.org/10.1016/S1352-2310(98)00395-1.

Kousoulidou M, Fontaras G, Ntziachristos L, Bonnel P, Samaras Z, Dilara P. Use of portable emissions measurement system (PEMS) for the development and validation of passenger car emission factors. Atmos Environ 2013;64:329-38. http://dx.doi.org/10. 1016/j.atmosenv.2012.09.062.

Kyriakis N, Samaras Z, Andrias A. MEET: road traffic composition. MEET deliverable 16. LAT report, n89823, Thessaloniki, Greece; 1998.

Markakis K, Poupkou A, Melas D, Tzoumaka P, Petrakakis M. A computational approach based on GIS technology for the development of an anthropogenic emission inventory of gaseous pollutants in Greece. Water Air Soil Pollut 2010;207:157-80. http://dx. doi.org/10.1007/s11270-009-0126-5.

Mellios G, Aalst RV, Samaras Z. Validation of road traffic urban emission inventories by means of concentration data measured at air quality monitoring stations in Europe. Atmos Environ 2006;40:7362-77. http://dx.doi.org/10.1016/j.atmosenv.2006.06.044

Noland RB, Quddus MA. Flow improvements and vehicle emissions: effects of trip generation and emission control technology. Transp Res 2006;D11:1-14. http://dx.doi.org/ 10.1016/j.trd.2005.06.003.

Ntziachristos L, Mellios G, Kouridis Ch, Papageorgiou Th, Theodosopoulou M, Samaras Z et al. European database of vehicle stock for the calculation and forecast of pollutant and greenhouse gases emissions with TREMOVE and COPERT - final report. LAT AUTh report no. 08.RE.0009.V2; 2008. p. 250 [Thessaloniki, Greece].

Ntziachristos L, Samaras Z. EMEP/EEA Emission Inventory Guidebook 2009, updated June 2010: exhaust emissions from road transport; 2010.

Odum JR, Jungkamp TPW, Griffin RJ, Flagan RC, Seinfeld JH. The atmospheric aerosolforming potential of whole gasoline vapor. Science 1997;276:96-9. http://dx.doi. org/10.1126/science.276.5309.96

OpenStreetMap data. OpenStreetMap is open data, licensed under the Open Data Commons Open Database License (ODbL). The cartography in the map tiles, and documentation, are licensed under the Creative Commons Attribution-ShareAlike 2.0 license (CC BY-SA); 2012. Available at: www.openstreetmap.org [Accessed October 2012].

Pant Pallavi, Harrison Roy M. Estimation of the contribution of road traffic emissions to particulate matter concentrations from field measurements: a review. Atmos Environ 2013;77:78-97. http://dx.doi.org/10.1016/j.atmosenv.2013.04.028.

Parrish DD, Trainer M, Hereid D, Williams EJ, Olszyna KJ, Harley RA, et al. Decadal change in carbon monoxide to nitrogen oxide ratio in U.S. vehicular emissions. J Geophys Res 2002;107(D12):4140. http://dx.doi.org/10.1029/2001JD000720.

Pilinis C, Kassomenos P, Kallos G. Modeling of the photochemical pollution in Athens, Greece. Application of the RAMS-CALGRID modelling system. Atmos Environ 1993; 27B:353-70. http://dx.doi.org/10.1016/0957-1272(93)90014-W

Poupkou A, Symeonidis P, Ziomas I, Melas D, Markakis K. A spatially and temporarily disaggregated anthropogenic emission inventory in the Southern Balkan region. Water Air Soil Pollut 2007;185:335-48. http://dx.doi.org/10.1007/s11270-0079457-2.
Poupkou A, Symeonidis P, Lisaridis I, Melas D, Ziomas I, Yay OD. Effects of anthropogenic emission sources on maximum ozone concentrations over Greece. Atmos Res 2008; 89:374-81. http://dx.doi.org/10.1016/j.atmosres.2008.03.009.

Progiou AG, Ziomas IC. Road traffic emissions impact on air quality of the Greater Athens Area based on a 20 year emissions inventory. Sci Total Environ 2011;410-411:1-7.

Progiou AG, Ziomas IC. Twenty year road traffic emission trend in Greece. Water Air Soil Pollut 2012;223:305-17. http://dx.doi.org/10.1007/s11270-011-0859-9.

Pusede SE, Cohen RC. On the observed response of ozone to NOx and VOC reactivity reductions in San Joaquin Valley California 1995-present. Atmos Chem Phys 2012;12: 8323-39. http://dx.doi.org/10.5194/acp-12-8323-2012.

Smit R, Ntziachristos L, Boulter P. Validation of road vehicle and traffic emission models a review and meta-analysis. Atmos Environ 2010;44(25):2943-53. http://dx.doi.org/ 10.1016/j.atmosenv.2010.05.022.

Souza CDR, Silva SD, Silva MAV, D'Agosto MA, Barboza AP. Inventory of conventional air pollutants emissions from road transportation for the state of Rio de Janeiro. Energ, Policy 2013;53:125-35. http://dx.doi.org/10.1016/j.enpol.2012.10.021.

Pateraki St, Assimakopoulos VD, Maggos Th, Fameli KM, Kotroni V, Vasilakos Ch. Particulate matter pollution over a Mediterranean urban area. Sci Total Environ 2013; 463-464:508-24. http://dx.doi.org/10.1016/j.scitotenv.2013.05.076.

Sullivan JL, Baker RE, Boyler BA, Hammerle RH, Kenney TE, Muniz L, et al. $\mathrm{CO}_{2}$ emission benefit of diesel (versus gasoline) powered vehicles. Environ Sci Technol 2004; 38(12):3217-23. http://dx.doi.org/10.1021/es034928d.

Symeonidis P, Ziomas I, Proyou A. Emissions of air pollutants from the road transport sector in Greece: year to year variation and present situation. Environ Technol 2003;24: 719-26. http://dx.doi.org/10.1080/09593330309385608.

Taghavi M, Cautenet S, Arteta J. Impact of highly detailed emission inventory on modelling accuracy. Atmos Res 2005;74:65-8. http://dx.doi.org/10.1016/j.atmosres.2004. 06.007

Tsilingiridis G, Zachariadis T, Samaras Z. Spatial and temporal characteristics of air pollutant emissions in Thessaloniki, Greece: investigation of emission abatement measures. Sci Total Environ 2002;300:99-113. http://dx.doi.org/10.1016/S0048-9697(02) 00170-5.

Vanhulsel M, Degraeuwe B, Beckx C, Vankerkom J, De Vlieger I. Road transportation emission inventories and projections - case study of Belgium: methodology and pitfalls. Transp Res D 2014;27:41-5. http://dx.doi.org/10.1016/j.trd.2013.12.002

Weiss M, Bonnel P, Kühlwein J, Provenza A, Lambrecht U, Alessandrini S, et al. Will Euro 6 reduce the NOx emissions of new diesel cars? - insights from on-road tests with Portable Emissions Measurement Systems (PEMS). Atmos Environ 2012;62:657-65. http://dx.doi.org/10.1016/j.atmosenv.2012.08.056

Winiwarter W, Doreb C, Hayman G, Vlachogiannis D, Gounaris N, Bartzis J, et al. Methods for comparing gridded inventories of atmospheric emissions-application for Milan province, Italy and the Greater Athens Area, Greece. Sci Total Environ 2003;303: 231-43. http://dx.doi.org/10.1016/S0048-9697(02)00473-4.

Zachariadis T. On the baseline evolution of automobile fuel economy in Europe. Energ Policy 2006;34:1773-85. http://dx.doi.org/10.1016/j.enpol.2005.01.002.

Zachariadis TI, Samaras Z. Comparative assessment of European tools to estimate traffic emissions. Int J Veh Des 1997;18(3/4, Special Issue):312-25.

Zamboni G, Capobianco M, Daminelli E. Estimation of road vehicle exhaust emissions from 1992 to 2010 and comparison with air quality measurements in Genoa, Italy. Atmos Environ 2009;43:1086-92. http://dx.doi.org/10.1016/j.atmosenv. 2008.11.014

Zervas $\mathrm{E} . \mathrm{CO}_{2}$ benefit from the increasing percentage of diesel passenger cars. Case of Ireland. Energ Policy 2006;34:2848-57. http://dx.doi.org/10.1016/j.enpol.2005.05. 010

Zervas E, Poulopoulos S, Philipopoulos C. $\mathrm{CO}_{2}$ emissions from the introduction of diesel passenger cars: case of Greece. Energy 2006;31:2915-25. http://dx.doi.org/10.1016/ j.energy.2005.11.005.

Ziomas I, Tzoumaka P, Balis D, Melas D, Zerefos C, Klemm O. Ozone episodes in Athens, Greece. A modelling approach using data from the MEDCAPHOT-TRACE. Atmos Environ 1998;31(12):2313-21. http://dx.doi.org/10.1016/S1352-2310(97)00414-7. 


\begin{tabular}{|c|c|c|c|c|c|c|c|c|c|c|c|c|}
\hline \multicolumn{13}{|c|}{ Hour (UTC) } \\
\hline 12 & 13 & 14 & 15 & 16 & 17 & 18 & 19 & 20 & 21 & 22 & 23 & 24 \\
\hline 0.061624 & 0.057618 & 0.051149 & 0.054139 & 0.060071 & 0.062160 & 0.058051 & 0.052042 & 0.054392 & 0.042819 & 0.033881 & 0.041780 & 0.037469 \\
\hline 0.054370 & 0.057500 & 0.059572 & 0.058842 & 0.061020 & 0.058895 & 0.053514 & 0.048669 & 0.043741 & 0.032773 & 0.024793 & 0.023396 & 0.015367 \\
\hline 0.054831 & 0.058197 & 0.058185 & 0.058226 & 0.060225 & 0.058420 & 0.053664 & 0.051521 & 0.047760 & 0.035110 & 0.026654 & 0.018800 & 0.012795 \\
\hline 0.057141 & 0.058592 & 0.058248 & 0.058356 & 0.060186 & 0.059149 & 0.055615 & 0.050894 & 0.048967 & 0.037230 & 0.029587 & 0.022503 & 0.016201 \\
\hline 0.054040 & 0.057411 & 0.057948 & 0.057158 & 0.059676 & 0.057219 & 0.053214 & 0.051803 & 0.047722 & 0.035117 & 0.027373 & 0.022105 & 0.014889 \\
\hline 0.053319 & 0.053895 & 0.052747 & 0.052998 & 0.05634 & 0.056447 & 0.053586 & 0.052762 & 0.052009 & 0.041373 & 0.033857 & 0.024667 & 0.023987 \\
\hline 0.057187 & 0.057686 & 0.055898 & 0.051944 & 0.053071 & 0.053835 & 0.053520 & 0.055065 & 0.054865 & 0.047651 & 0.041959 & 0.032846 & 0.026871 \\
\hline 0.048342 & 0.044919 & 0.046423 & 0.051574 & 0.054943 & 0.058518 & 0.057299 & 0.056102 & 0.048485 & 0.044249 & 0.044108 & 0.040602 & 0.033653 \\
\hline 0.054573 & 0.056797 & 0.056642 & 0.058822 & 0.056411 & 0.052191 & 0.048012 & 0.044917 & 0.033351 & 0.026576 & 0.030558 & 0.018547 & 0.010308 \\
\hline 0.056603 & 0.056910 & 0.056273 & 0.058423 & 0.056535 & 0.053139 & 0.051578 & 0.04926 & 0.033231 & 0.028119 & 0.021892 & 0.015076 & 0.009145 \\
\hline 0.055784 & 0.055449 & 0.055728 & 0.057963 & 0.056676 & 0.053643 & 0.050557 & 0.048199 & 0.037689 & 0.030014 & 0.023543 & 0.015008 & 0.009308 \\
\hline 0.055829 & 0.055938 & 0.056675 & 0.056429 & 0.054714 & 0.052915 & 0.050037 & 0.049524 & 0.037920 & 0.029995 & 0.025316 & 0.017328 & 0.010300 \\
\hline 0.054922 & 0.055477 & 0.054806 & 0.056239 & 0.054761 & 0.051800 & 0.049441 & 0.049439 & 0.037967 & 0.031678 & 0.024928 & 0.018240 & 0.011543 \\
\hline 0.054632 & 0.050507 & 0.046173 & 0.046454 & 0.049885 & 0.053010 & 0.054386 & 0.053918 & 0.046559 & 0.042162 & 0.033737 & 0.028327 & 0.021673 \\
\hline
\end{tabular}

